Cilt: 19, Say1:1, 2021, ss. 1-28｜Ｖolume: 19, Issue:1, 2021, pp. 1-28

\title{
Impurity in Terms of Human Ontology: al-Tawba 9/28
}

İnsan Ontolojisi Bakımından Necislik: Tevbe 9/28 Örneği

\section{Rabiye ÇETIN}

Doç. Dr., Ankara Üniversitesi, İlahiyat Fakültesi, Ankara/Türkiye Associate Professor, Ankara University, Faculty of Theology, Ankara/Turkey rgecdogan@gmail.com | orcid.org/0000-0002-4706-0022 | ror.org/01wntqw50

$$
\begin{aligned}
\text { Makale Bilgisi } & \text { Article Information } \\
\text { Makale Türü } & \text { Article Type } \\
\text { Araştırma Makalesi } & \text { Research Article } \\
\text { Geliş Tarihi } & \text { Date Recieved } \\
15 \text { Nisan 2021 } & 15 \text { April 2021 } \\
\text { Kabul Tarihi } & \text { Date Accepted } \\
27 \text { Haziran 2021 } & \text { 27 June 2021 } \\
\text { Yayın Tarihi } & \text { Date Published } \\
30 \text { Haziran 2021 } & \text { 30 June 2021 } \\
\text { İntihal } & \text { Plagiarism }
\end{aligned}
$$

Bu makale, iTenticate yazılımı ile taranmıştır. İntihal This article has been scanned with iTenticate software. No plagiarism detected.

\section{Etik Beyan Ethical Statement}

Bu çalışmanın hazırlanma sürecinde bilimsel ve etik It is declared that scientific and ethical principles ilkelere uyulduğu ve yararlanılan tüm çalışmaların kaynakçada belirtildiği beyan olunur (Rabiye Çetin). have been followed while carrying out and writing this study and that all the sources used have been properly cited (Rabiye Çetin).

CC BY-NC-ND 4.0 lisansı ile lisanslanmıştır. Licensed underCC BY-NC-ND 4.0 license. 


\section{Abstract}

In this article, the literature set forth in the Muslim tradition of thought on the nature of social relations with polytheists is discussed in general terms. The literature in question has been formed based on the verse "...Do not allow polytheists to approach al-Masjid al-Ḥaām after this year" (Tawba 9/28). In this context, scholars discussed such issues as the nature of the polytheism, the content of the act of not approaching the borders of al-Masjid al-Harām region, and especially whether the warning in the verse is limited to the worship of Hajj. It is seen that two views come to the fore in the literature presented within the framework of this verse. The first one expands the boundaries of the prohibition of not approaching, considering that the meaning of the term al-Masjid al-Harām covers all mosques, while the other view is based, with an interest centered approach, on the claim that the area in question is limited to the Ka'ba and its surroundings. In this context, it is argued that the polytheists cannot enter the area of Harām at all, while the second view emphasizes that the polytheists cannot enter the area in order to perform pilgrimage and umrah in the way they did in the time of ignorance, but they can come for different purposes such as trade, travel etc. In the article, the subject is examined with reference to riwāyah, dirayāh, ahkām, and Shiite tafsirs written until the seventh century of Hijra. In this context, the ahkâm tafsirs by Muqātil b. Sulaymān, Imām Shāficī, al-Jaș̦̣āș, Abū Bakr Ibn al-'Arabī and al-Qurțubī; the narration tafsirs by al-Ṭabarī, Ibn Abī Ḥātim, Abū Ishāq al-Tha labī and Ibn Kathīr; the dirayāh tafsirs by al-Māturīiñ, alZamakhsharī, Fakhr al-Din al-Rāzī, al-Bayḍāwī and Abū al-Barakāt al-Nasafī, and the Shiite tafsirs by al-Qummī, alAyyāshī, Abū Ja'far al-Tūsī and al-Tabarsī have been studied. The purpose of dealing with the subject based on the aforementioned tafsirs is to make a comparison by determining the legal provisions put forward depending on the understanding of the verse and their reasons. Indeed, it is seen that the views of the scholars described as Aṣāa alHadīth and Așhāb al-Ra'y are determinant in understanding the 28th verse of the sūrat al-Tawba. The purpose of examining the Shiite tafsirs in the context of the subject is to determine whether the perspective regarding the handling of the 28th verse of the sūrat al-Tawba is close to that of Așhāb al-Ḥadīth or Așhāb al-Ra'y in the literature in question. In the tafsir works examined, it is stated that the first opinion belongs to Imām Mālik and Imām Shāfi ī̄, while the second opinion is attributed to Abū Hanifa. While the view belonging to Imām Malik and Imām Shāfici has been generally accepted, the second view adopted by Abū Ḥanīfa hand al-Māturīìi and accepted by Hanafi-Māturīdī scholars has been described as exceptional (shadhdh) in the historical process and not taken into consideration. In the article, the basic logic of these views, their emergence processes and the juridical provisions produced within this framework, specific to the riwāyah, dirayāh, ahkām and Shiite tafsirs written until the seventh century of Hijra are attempted to be examined from an analytical perspective. As a result, it is seen in the article that Imām al-Mālik and Imām al-Shāfīī, the members of Așhāb al-Ḥadith, discuss the issue in a way that includes not only polytheists but also all non-Muslims, and put forward legal provisions on the nature of the social, economic and political relations to be established with these groups. With these provisions, the marginalization of non-Muslims, especially socio-culturally, in the Muslim intellectual tradition has been legitimized. This point of view not only prevents Muslims from contributing to the culture of living together, but also contradicts with the perspective of the Qur'ān, which is based on respect for human beings. In this context, Abū Hanīfah, one of the prominent representatives of Aṣ̣āb al-Ray, restricts the prohibition order to the act of pilgrimage during the period of ignorance, allowing for serious differences in the point of view on the subject. This way of understanding of Abū Ḥaniffah does not allow for a negative practice regarding non-Muslims and has been developed by his follower al-Māturīdī and taken into a moral dimension.

Keywords: Kalam, Polytheism, Polytheist, The 28th verse of Surāt al-Tawba, al-Masjid al-Ḥarām, Abū Ḥanīfah, alMāturīdī. 


\section{Öz}

Bu makalede, müşriklerle sosyal ilişkinin mahiyetine dair Müslüman düşünce geleneğinde ortaya konulan literatür genel hatlarıyla ele alınmaktadır. Söz konusu literatür, "müşrikler bu yıldan sonra Mescid-i Harâm’a yaklaşmasınlar" (Tevbe 9/28) ayeti temelinde şekillenmiştir. Bu bağlamda âlimler şirkin mahiyeti, Mescid-i Harâm bölgesinin sınırları ile bu bölgeye yaklaşmamayı ifade eden fiilin içeriği ve özellikle de ayetteki uyarının Hac ibadeti ile sınırlı/kayıtlı olup olmadığı gibi hususları tartışma konusu yapmışlardır. Bu ayet çerçevesinde ortaya konulan literatürde iki görüşün ön plana çıktığı görülmektedir. Bunlardan ilki, Mescid-i Harâm ifadesiyle kastedilen mananın tüm mescitleri kapsayacağı düşüncesinden hareketle "yaklaşmama" yasağın sınırlarını genişletirken diğer görüş, maslahatçı bir yaklaşımla söz konusu bölgenin Kâbe ve çevresiyle sınırlı olduğu iddiasına dayanmaktadır. Bu bağlamda ilk görüşte, harem bölgesine müşriklerin hiçbir surette giremeyeceği savunulurken ikinci görüşte, müşriklerin cahiliye döneminde yaptıkları tarzda hac ve umre ibadeti yapmak amacıyla söz konusu bölgeye giremeyecekleri ancak ticaret, seyahat vb. farklı maksatlarla gelebilecekleri vurgulamaktadır. Makalede konu H. VII. yüzyıla kadar kaleme alınan rivayet, dirayet, ahkâm ve Şiî tefsirler temelinde irdelenmiştir. Bu bağlamda Mukātil b. Süleymân, İmâm şâfiî, Cassâs, Ebû Bekir İbnü'l-Arabî ve Kurtubî̀nin kaleme aldığı ahkâm tefsirleri; Taberî, İbn Ebî Hâtim, Ebû İshak es-Sa'lebî ve İbn Kesîr'in yazdığı rivayet tefsirleri; Mâtürîdî, Zemahşerî, Fahreddin er-Râzî, Beyzâvî ve Ebu'l- Berakât en-Nesefî̀nin dirayet tefsirleri ile Şî̂ müfessirler Kummî, Ayyâşî, Ebû Ca'fer et-Tûsîve Tabersînnin tefsirleri incelenmiştir. Konunun bahsi geçen tefsirler temelinde ele alınmasındaki amaç ayetin anlaşılmasına bağlı olarak ortaya konulan fikhî hükümleri ve gerekçelerini tespit ederek mukayese yapmaktır. Zira Tevbe suresi 28. ayetin anlaşılmasında, dini anlama tarzları bakımından Ashâbu'l-Hadis ve Ashâbu'r-Rey olarak nitelenen âlimlerin görüşlerinin belirleyici olduğu görülmektedir. Konu bağlamında Şîi tefsirlerin incelenmesindeki amaç ise söz konusu literatürde Tevbe suresi 28. ayetin ele alınmasına ilişkin bakış açısının Ashabu'l Hâdis'e mi Ashabu'r-Rey'e mi yakın olduğunu tespite yöneliktir. İncelenen tefsirlerde ilk görüşün İmâm Mâlik ve İmam Şâfî̉ye ait olduğu belirtilirken ikinci görüş Ebû Hanîfe'ye nispet edilmiştir. İmâm Mâlik ve İmam Şâfiî̀ye ait olan görüş genel kabul görürken Ebû Hanîfe ve Mâtürîdî’nin benimsediğgi, Hanefî-Mâtürîdî âlimler tarafından kabul gören ikinci görüş, tarihsel süreçte şaz olarak nitelendirilmiş ve dikkate alınmamıştır. Makalede, H.7. yüzyll'a kadar yazılan rivayet, dirayet, ahkâm ve Şîi tefsirleri özelinde bu görüşlerin temel mantı̆̆ı, ortaya çıkış süreçleri ve bu çerçevede üretilen fikhî hükümler analitik bir bakış açısıyla irdelenmeye çalışılmıştır. Makalede sonuç olarak Ashabu'lHadis'e mensup âlimlerden İmâm Mâlik ve İmâm Şâfî̀’nin konuyu sadece müşrikleri değil tüm gayr-i müslimleri içerecek şekilde ele aldıkları ve bu gruplarla kurulacak sosyal, ekonomik ve siyasi ilişkinin mahiyeti hakkında fihkî hükümler koydukları görülmektedir. Bu hükümlerle, Müslüman düşünce geleneğinde gayr-i Müslimlerin özellikle sosyo-kültürel açıdan ötekileştirilmeleri meşrulaştırılmıştır. Bu bakış açısı Müslümanların birlikte yaşama kültürüne katkı sağlamalarını engellediği gibi insana saygıyı temel alan Kur'an'ın bakış açısı ile de çelişmektedir. Bu bağlamda Ashabu'r-Rey'in önemli temsilcilerinden biri olan Ebu Hanîfe'nin yasaklama emrini cahiliye döneminde yapılan hac fiili ile sınırlaması konuya ilişkin bakış açısında ciddi farklılıklara imkân tanımaktadır. Ebû Hanîfe'nin bu anlama biçimi, gayr-1 Müslimlere ilişkin olumsuz bir uygulamaya imkân vermediği gibi takipçisi Mâtürîdî tarafından geliştirilerek ahlakî bir boyutta ela alınmıştır. Süreç içerisinde söz konusu anlama biçimi, aynı düşünce geleneğine mensup olan Cassâs ve Ebû'l-Berekât enNesefî tarafından devam ettirilerek geliştirilmiştir.

Anahtar Kelimeler: Kelam, Şirk, Müşrik, Tevbe suresi 28. ayet, Mescid-i Harâm, Ebû Hanîfe, Mâtürîdî. 


\section{Introduction}

Having a special position in the hierarchy of beings due to their abilities, the primary concern of man has always been to question the ways of making sense of his own existence, adding value to his existence, and thus becoming visible and effective. Based on the philosophy of life, human beings can function as a subject as well as an object. One of the primary areas in which man realizes his existence is his mental background, where he exists as a subject and object- as he is open to external influence-, and determines his perception and attitudes towards his role in society. History, culture, religion, ethnic origin, social structure etc. are the basic factors that determine the human mind. As these factors determine the self-perception of the human being, they shape the perception and attitude towards himself and people outside of nature with all its elements. Religion, one of the above-mentioned factors that determine the human mind, turns into a perspective that permeates all aspects of human life, partially infiltrating culture, partially into history and partially into the social structure. In this respect, religion, which has an effective function in encompassing the codes of the human mind, can be the key to reconciliation as well as the key to discrimination and marginalization.

The human being as a subject of life is an entity that objectifies and alienates other people due to differences such as culture, belief, thought, language, religion, and ethnic origin. The understanding of religion plays a decisive role in the relationship that an individual, who perceives all the areas of existence outside of himself through his own mental world, establishes with other in individual, social, cultural, legal and political contexts. Inquiries about the function of religion gain meaning in this context. What is the ultimate goal of religion(s)? Do religions aim to exist on a ground that aims at the happiness and peace of their own followers? Which decompose, ignore and exclude differences, or do they aim to create themselves on a basis of reconciliation within the framework of the fundamental rights of the person they address? These questions require questioning the meaning and function that religious people attribute to religion as well as the function of religion. In the historical process, the dominance of the exclusionary/marginalizing discourse in the religious culture peculiar to Judaism, Christianity and Islam is remarkable. The effort to make sense of one's own religion and religiosity through the other has led to the neglect of religion's contribution to the creation of a culture of consensus. The indispensable and inviolable fundamental rights of human beings, which express the protection of life, mind, generation, religion and property, have been violated on religious grounds.

One of the verses that have a decisive effect on the literature regarding the nature of the relationship of Muslims with non-Muslims, especially with polytheists, is the following verse: "O you who have believed, indeed the polytheists are impure, so let them not approach al-Masjid al-Ḥarām after this, their [final] year. And if you fear privation, Allāh will enrich you from His bounty if He wills. Indeed, Allāh is Knowing and Wise." The verse in question is understood in the classical literature to allow the protection of the fundamental rights of human beings, as well as the restriction and denial of these rights, and has been used as evidence in the ways of

al-Tawba $9 / 28$. 
making and implementing juridical judgments. When the literature regarding the position of the polytheists in social life that formed in the context of 28th verse of surat al-Tawba is evaluated, it is seen that the subject is discussed under four main headings. The first of the topics of discussion is to determine the nature of the verb not to approach the mosque, the second to the impure, the third to the impure. The first of the discussion topics is to determine the nature of the polytheism/polytheist, the second of the impurity (najs), the third of masjid and the last one of the act of not approaching.

In the article, the views expressed in the frame of verse 28 of sürat al-Tawba ${ }^{2}$ are examined in the context of classical tafsirs written until the seventh century of the Hijra. The verse in question is one of the verses that were discussed in detail in the riwāyah, dirayāh and ahkām tafsirs and on which legal provisions were built. In this respect, the 28th verse of sūrat al-Tawba is one of the verses where the perspectives of Kalam, Fiqh and Tafsir disciplines concur regarding the nature of the relationship to be established with polytheists and members of other religions. In the classical literature about the verse in question, it is seen that the views of the scholars who are described as Așhāb al-Ḥadīth and Așhāb al-Ra'y are determinant in terms of their religious understanding. In the context of this verse, by examining the interpretations written with different methods since the early period, it is aimed to determine the perspectives of Așhāb al-Ḥadìth and Aṣhāb al-Ra'y, in other words, the framework of the mentality codes, and whether there has been any change in these perspectives in course of time. In this context, the subject has been studied with reference to the ahkâm tafsirs by Muqātil b. Sulaymān (d. 150/767), Imām Shāficī (d. 204/820), al-Jașṣāṣ (d. 370/981), Abū Bakr Ibn al-'Arabī (d.543/1148) and al-Qurțubī (d. 671/1273); the riwāyah tafsirs by al-Ṭabarī (d. 310/923), Ibn Abī Ḥātim (d. 327/938), Abū Ishāq al-Tha'labī (d. 427/1035) and Ibn al-Kathir (d. 774/1373); the dirayāh tafsirs by al-Māturīdī (d. 333/944), al-Zamakhsharī (d. 538/1144), Fakhr al-Din al-Rāzī (d. 606/1210), alBayḍāwī (d. 685/1286) and Abū al-Barakāt al-Nasafī (d. 710/1310), and the Shiite tafsirs by alQummī (d. 209/903), Ayyāshī (d. 320/932), Abū Ja'far at-Tūsī (d. 460/1067) and al-Ṭabarsī (d. 548/1124). Different perspectives put forward for understanding the verse are possible by examining the culture created accordingly. In this context, while the descriptive method is used in the presentation of the literature in question, the analytical method has been used in terms of comparing the socio-cultural environment, events and facts that lead to the emergence of different opinions.

\section{Nature of Polytheism}

At the center of the tradition of revelation is a vision of God based on the oneness of God (tawhid). However, it is a historical fact that this vision differs within the various experiences of

Articles are noteworthy in the literature review conducted in the context of sūrat al-Tawba 28. For the first of these articles, see. Süleyman Kaya, "Harem Bölgesine Girişin Yasaklanması (Tevbe 28. Ayetin Anlamı Bağlamında)", AiBÜ Sosyal Bilimler Enstitüsü Dergisi 15/2 (2015), 307-332. In this article, the meaning area of the verse is tried to be determined on the basis of the relationship between sirat and inzal. For the second study, see. Muhammed Çucak, "Gayrimüslümlerin Temiz Olup-Olmamasının Değerlendirilmesi ve Fıkhî Sonuçları", Bülent Ecevit İlahiyat Fakültesi Dergisi 4/1 (2017), 55-72. In this study, the nature of the social relations to be established with non-Muslims is examined and the legal provisions regarding whether the belongings of the people in question are clean and the Muslims eating and drinking something from these items are examined. 
this tradition. One of these differentiating imaginations is shirk, which is defined as the acceptance of other common entities that are equivalent to the divinity and lordship of one transcendent being that creates and maintains the universe. ${ }^{3}$ According to this view, God is such a sublime and transcendent being that man cannot communicate. People who want to communicate with God believe that communication can only be achieved through respect, honor and servitude to intermediary beings. This imagination called as shirk/polytheism in the Qur'ān, ${ }^{4}$ shows that besides the existence of God, man's own existence cannot be perceived in accordance with his own ways of being. For, there is a complete contrast between the creator and the created in terms of the existential nature. The intermediary entities that are asked for help to overcome this contrast are in a lower position in terms of the existential qualities of human beings. In this respect, shirk causes people to move away from the inherent idea of oneness and to become alienated from their own existence, as well as blurring his perception of the truth. In this respect, in the Qur'ān, polytheism is described as a slander, ${ }^{5}$ cruelty ${ }^{6}$ to God and the greatest $\sin ^{7}$ that, if not repented, cannot be forgiven. Because the concept of shirk eliminates the ontological distinction between the creator and the created, and causes the creator's attributes to be attributed to creatures and the divine and human realms to be confused.

It is possible to describe the history of man-the tradition of revelation in other words - as the struggle of tawhid and shirk. The inherent nature of the idea of tawhid, which is the basis of religion, requires that a person behave in accordance with his inherent nature. Human beings tend to truth/reality by acting in accordance with the codes of existence, and he is called as hanif $^{8}$ for this action. Tawhid, due to its nature and rationality, enables people to transfer their innate dignity to a practical dimension with their own actions and to maintain and preserve this dignity.

It is seen that the boundaries of the idea of oneness are clearly determined in the Qur'ān and the forms of imagination outside of oneness are regarded as infidelity/denial. Shirk and infidelity (kufr) are associated with each other in terms of their imagination to accept the existence and unity of Allah or not. However, the point that should not be overlooked is that the shirk and kufr are controversial forms of imagination, the former accepts the existence of God, while the latter denies God. It is beneficial to examine the meaning difference between the two words in terms of lexical meaning and usage areas. The word derived from the root "شرك" has two basic uses, namely shirkat and sharak. Shirkat refers to the inability to own something alone, to share the same thing, to share, while the word sharak refers to something stretches, spreads and is heard. ${ }^{9}$

Abū al-Qāsim Ḥusain b. Muhammad b. al- Mufaḍdal al-Rāghīb al- Isfahānī, Mufradāt fì Gharib al-Qur'ān, Critical ed. Muhammad Sayyid Kīlānī (Beirut: Dār al-Maarif, n.d.), "sh-r-k”, 259-260; Muhammad Aclā b. 'Alī b. Qāḍi MuhammadḤāmidal-Tahānawī, Kashshāf Ișțilāhāat al-Funūn wa al-‘Ulūm, Critical ed. 'Alī Dahrūj- 'Abd Allāh Khālidī (Beirut: Maktabaal-Lubnān, 1996), "shirk",1/1021-1024.

al-A'rāf 7/37; Yūnus 10/106; al-Nahl 16/73; al-Rūm 30/13; al-Zumar 39/3.

al-Nisā' $4 / 48$.

Luqmān 31/13.

al-Nisā̄ 4/116.

Āl 'Imrān 3/67, 95; al-Nisā’' 4/125; al-An'ām 6/79, 161; Yūnus 10/105; al-Rūm 30/30; al-Bayyina 98/5. Abū Ḥusayn Aḥmad b. Fāris, MújamMaqāyīs al-Lughah, Critical ed. 'Abd al-Salām Muhammad Harun (s.l.: Dār alFikr, n.d.), "sh-r-k", 3/265. 
The spread and dispersion in the word sharak also has a meaning expressing the branches and side paths leaving the trunk. ${ }^{10}$ However, it is accepted that the word shirk is derived from the shirkat infinitive. ${ }^{11}$ This root, which expresses partnership and sharing, requires examining the nature of partnership-sharing. Accordingly, the partnership can be on a qualification that belongs to the essence or the genre. In this context, based on the examples of man and horse, alIsfahani gives the fact that human beings and horses possess vitality, which is an essential quality, as an example of partnership in essence. He gives the two horses having the same color an example for a generic partnership, which expresses the characteristic that two or more beings have in common. Thus, he explains being a partner of any material or spiritual nature with the word shirk/shirkat. ${ }^{12}$ While this partnership is natural in the realm of contingent being, it is contrary to the nature of necessary being. In this respect, accepting the essential or generic partnership of necessary being is defined as shirk and condemned.

It is also reported that the word shirk was used over time instead of the word " كفر (kufr). ${ }^{13}$ It is seen that the understanding of the usage areas of the word shirk in the Qur'ān is determinant in the use of the word kufr instead of shirk. In the Qur'ān, kufr is also used to mean accepting a god other than Allah. ${ }^{14}$ In this respect, shirk and kufr are positioned as the opposite of the conception of God based on tawhid, which is determined and emphasized as the basis of faith in the Qur'an and used not only as an expression of infidelity, but also of the inability to perceive existence and to develop a belief as per it. In addition to this basic synonymity, there is a content-extension relationship between shirk and kufr. While every attitude and behavior related to shirk can be considered within the scope of kufr, not every attitude and behavior of kufr can be regarded as shirk.

Regarding the content of the naming of the mushrik(a), which expresses the subject of shirk action, there is a disagreement among scholars especially on the basis of the al-Baqarah 2/221. While some of the scholars state that only idolaters are meant by this name, some of them argue that the People of the Book are included in this description together with the polytheists. The scholars who argue that the expression of mushrik only refers idolaters substantiate their views by arguing that the distinction between the mushrik and the People of the Book is clearly made in al-Baqara 105, al-Mā'ida 82, al-Hajj 17 and al-Bayyina $1 .{ }^{15}$ The scholars who believe that the word mushrik refers to the People of the Book as well as the polytheists prove their opinion by

10 Abū Bakr Muhammad b. al-Ḥasan b. Durayd, Djamharatu'l-Lughah, Critical ed. Ramzī Munīr al-Ba‘labakkī (Beirut: Dār al-'Ilm li al-Malāyīn, 1987), "sh-r-k", 2/732-733.

11 Muhammad b. Mukarram Ibn Manzūur, Lisān al-'Arab, Critical ed. 'Abd Allāh 'Alī al-Kabīr et al. (Cairo: Dār al-Maārif, n.d.) "shirk", 4/2248-2250.

12 al-Iṣfahānī, "sh-r-k", 259.

13 Ibn Manz̦ūr, "kufr", 5/3898; Abū Nașr Ismāčil b. Ḥammād al-Djawharī, Mújam al-Ṣıhah, Critical ed. Ahmad'Abd-alĠafūr'Aț̣ārr (Beirut: Dār al-‘Ilm li al-Malāyīn, 1979/1399), "kufr”, 2/807.

$14 \quad \bar{A} l$ ' Imrān 3/151; al-Mā’ida 5/72-73; al-Tawba 9/30; al-Bayyina 98/1-6.

15 Muhammad b. al-Jarīr al-Ṭabarī, Jāmic al-Bayān 'an Tawīl Ây al-Qur'ān, Critical ed. 'Abd Allāh b. 'Abd al-Muḥsin alTurkī (Cairo: Dār al-Ḥijr, 2001/1422), 2/386; Şihāb al-Dīn Mahmūī al-Ālūsī, Rūḥ al-Ma'ānī fì Tafsīr al-Qur'ān al-'Azīm wa al-Sab' al-Mațānī (Beirut: Ihyya Turāth al-'Arabī, n.d.),1/349-350, 7/2, 17/128-130; SeeH. Mehmet Soyalan, İnançla İlgili Temel Kavramlar (İzmir: Çağlayan Yayınları, 1997), 68-71. 
the condemnation of the Jews and Christians for committing the act of shirk by attributing a son to Allāh in the verses 73 of the sūrat al- Mā̄ida and 30 of the sūrat al-Tawba. ${ }^{16}$

\section{Najas/The Nature of Impurity}

In the 28th verse of the sūrat al-Tawba, the polytheists are described as being najas/impure. This word is used in the verse as adjective describing polytheists in the context of shirk. In the study, information is given about the etymological structure of the word najas in all tafsirs until the seventh century of hijra. The word najas is the infinitive of the verb " "نج" and means dirty. Al-Rāzi quotes from al-Layth that the word najas is used to describe people and other things that are filthy. ${ }^{17}$ The Shiite mufassir al-Ṭabarsi states that the word is used to express all kinds of pollution due to its being an infinitive. ${ }^{18} \mathrm{Al}-\mathrm{Tha}$ "labi states that the word " "نجّ" coming from this

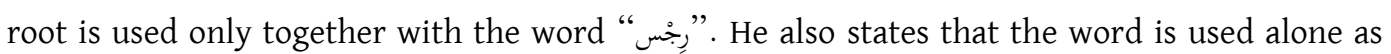

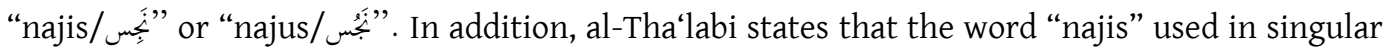
cases does not mean impurity in itself, but de jure, and that Abū Ubayda and al-Dahhak explain

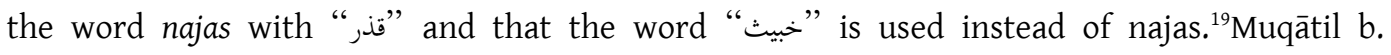
Suleymān also states that the words in question are synonymous. ${ }^{20}$ In essence, the word (khabath) or impurity or something dirty. In essence, the word khubth refers to the inner bad and

16 Fakhr al-Dīn al-Rāzī, Mafātīh al-Ghayb, (Beirut: Dār al-Fikr, 1981/1401), 6/59-60, 12/64-68, 16/34-39; Muhammad ibn Yūsuf Abū Ḥayyān al-Andulisī, al-Bahru'l-Muhịt, Critical ed. 'Adil Aḥmed 'Abd al-Mawjūud et al. (Beirut: Dār alKutub al-'Ilmiyye, 1993/1413), 5/28. For example, based on the sūrat al-Tawba, Fakhral-Dīn al-Rāzī argues that polytheism is a kind of infidelity, so the term polytheist refers not only to those who associate shirk with Allah but to anyone who does not recognize and accept Allah properly. al-Rāzi who states that most of the mufassirs are of the opinion that the term mushrikdenotes the polytheists argues that the mufassirs based their views on the definition of shirk as an unforgivable sin in the 48th verse of sūratal-Nisa.However, al-Rāzī thinks that such a point of view is wrong. Stating that unbelief is a more general expression than shirk, al-Rāzì argues that Shirk is a more special vision within unbelief. Therefore he considers the relationship between shirk and kufr as a contentextension relationship. Therefore, extending the description of mushrik in the verse to the general, al-Rāzī states that this expression is valid for all unbelievers. Fakhr al-Dīn al-Rāzī, Mafātīh Ghayb,16/25. It should also be noted that among the tafsirs examined here, none of the works other than al-Rāzī's Mafātīh al-ghayb have specifically examined the nature of the relationship between shirk and kufr. Although they have not dealt with the relationship between shirk and kufr, it is seen that mufassirs other than al-Rāzī also consider shirk at the same level as kufr. Infact, after mentioning the verse in their works, the aforementioned mufassirs discuss the issue within the framework of the qualification of kufr. As an example of these tafsirs see Abū al-Hasan Muqātil b. Sulaymān, Tafsīr Muqātil b. Sulaymān,Critical ed. 'Abd Allāh MaḥmudShahhāta (Beirut: Mu'assasa al-Tārīkh al'Arabī, 2002), 2/165-166; Abū Ishāq al-Tha'labī, al-Kashf wa al-Bayān 'an Tafsīr al-Qur'ān, Critical ed. Imam Abū Muhammad b. Āshūr (Beirūt: Dār al-Ihyāal-Turāth al-‘Arabī, 2002), 5/26; 'Abd Allāh Ibn 'Umar Muhammad alBayḍ̄̄īi, Anwār al-Tanzīl wa Asrār al-Te’vīl, Critical ed. Muhammed 'Abd al-Raḥmān al-Marashlı (Beirūt: Dār al-Ihyā wa al-Turās al-'Arabī, n.d.), 3/77; Abū Manșūr al-Māturīdī, Ta’wīlāt al-Qur’ān, Critical ed. Ertuğrul BoynukalınProofreader Bekir Topaloğlu (İstanbul: Dār al- Mīzān Yayınları, 2006), 6/324-325.

17 Fakhr al-Dīn al-Rāzī, Mafātīh al-Ghayb, 16/25.

18 Amīn al-Islāmal-Faḍl Ibn al-Ḥasan Ṭabarsī, Majma al-Bayān fì Tefsīr al-Qur'ān, (Beirūt: Dār al-Murtaḍā, 2006), 5/30.

19 al-Tha 'labī, al-Kashf wa al-Bayān, 5/26. The word khabith is used to describe entities, states and situations no matter they are concrete or abstract that are not liked because they are worthless and ugly. al-Ișfahānī,"khubth”, 141. This word is also used for bad-smelling, nauseating foods. al-Ișfahānī, "kha-ba-th", 3/1088-1089. 
treacherous thoughts, but has a meaning area that includes the false in belief, the lie in the word, and the evil and ugliness in behavior. ${ }^{21}$ While the word najas is used only in the meaning of dirty in the verse 28 of sūrat al-Tawba in the Qur'ān, the word khubth is used only in the verse 157 of the sūrat al-Araf to express material filth. Other uses describe false beliefs, behaviors and bad words. ${ }^{22}$

The use of the words nics and rics together evokes the connotation that these words can express close or even the same meaning. In this respect, the meaning of the word rics is important in terms of the subject. Rics means filthy, filth, bad deeds and odors, sin, torment, blasphemy, doubt, delusion of the devil. ${ }^{23}$ Al-Ișfahānī states that something can be rics/filthy in four ways, including temperament, reason, evil or all. He gives an example of the pollution that is described as dirty in all its dimensions and states that the carcass is characterized by being dirty in terms of temperament, mind and evil. In addition, he describes pork as something that is dirty in terms of sharia, and alcohol and gambling as something that is dirty in terms of sharia and reason. Al-Ișfahānī explains the reason why the words "rics" are used in the 125th verse of sūrat al-Tawba and 100th verse of sūrat al-Yūnus is that the shirkis bad by reason. Because, reason is a capability that enables to avoid bad things. ${ }^{24}$

The main issue to be focused on in the light of the above information is to determine how the word "najas" is understood in the context of verse 28 of sūrat al-Tawba. Scholars disagree about the reason why polytheists are qualified as najs. Indeed, while some of the scholars claim that the polytheists are described as such because of their inherently dirty nature, some think that they are described as such because they do not pay attention to the cleanliness of their body and clothes and do not take ghusl wudu. According to another view, polytheists are described as spiritually dirty because they associate shirk with Allāh and their beliefs are not true. It is useful to explain these views in detail.

a. View that regards polytheists as dirty per se: The view that the polytheists are ontologically dirty is based on several reasons. The first of these reasons is the statement quoted from Ibn Abbas "Polytheists are dirty like dogs and pigs in terms of their nature." The second reason is the statement quoted from Ḥasan Bașrī, "Whoever shakes hands with a polytheist should perform ablution." ${ }^{26}$ Although the majority of the ulama does not accept

\footnotetext{
21 al-Ișfahānī, "khubth", 141.

22 Āl 'Imrān 3/ 179; al-Nisā'4/2; Ibrāhīm 14/26; al-Anbiyā’21/74; al-Nūr24/26.

23 Ibn Manẓūr, "rijs", 5/1590; al-Djawharī, "rcs", 3/933.

24 al-Ișfahānī, "rjs", 188.

25 Muhammad Ibn 'Umar al-Zamakhsharī, al-Kashshāf 'an Haqā̄iq Ghawāmiḍ al-Tanzil wa 'Uyūn al-Aqāwīl fi Wujūh alTa’wīl, Critical ed. Sheykh 'Adil 'Aḥmad 'Abd al-Mawjūd (Riyaḍ: Maktaba al-Abyakān, 1998/1418.) 1. Edition, 3/3031; al-Bayḍ̄̄wī, Anwār al-Tanzìl, 3/77; al-Tha'labī, al-Kashf wa al-Bayān, 5/27; al-Ṭabarī, Jāmi' al-Bayān 'an Ta'wīl Āy alQur'ān,11/399; Abū Muhammad 'Abd al-Rahmān Ibn Abī Ḥātim, Tafsìr al- Qur'ān al-'Az̦ìm, Criticaled. As'ad Muhammad Tayyib (Riyaḍ: Maktaba al-Nizār Muștafā, 1997/1417)1. Edition, 6/ 1775.

26 al-Zamakhsharī, al-Kashshāf, 3/30-31; Fakhr al-Dīn al-Rāzī, Mafātịh al-Ghayb, 16/ 25; Abū 'Abdullāh Muhammad b. 'Aḥmad al-Qurțubī, al-Jāmic li Aḥkām al-Qur'ān, Critical ed. 'Abd Allāh bin 'Abd al-Muhsin al-Turkī (Beirut: Muasasa al-Risāla, 2006), 10/152; al-Ṭabarī, Jāmi' al-Bayān 'an Ta’wīl Āy al-Qur'ān,11/399; al-Tha'labī, al-Kashf wa al- Bayān, 5/27; Abū Ca'far Muhammad b. Ḥasan at-Tūsī, at-Tibyān fiTafsìr al-Qur’ān, Critical ed. Ahmad Ḥamid Kasīr al-Amilī (s.l.: Dar al-Ihya al-Turath al-Arabī, n.d.), 5/201.
} 
the opinion that the polytheists are inherently unclean, it is seen that many Sunnī and Shiite tafsir sources include these narrations in terms of explaining the issue. ${ }^{27}$

It is stated in the tafsirs that the Imāms of the sects do not accept the view reported from Ḥasan al-Bașrī and Ibn al-'Abbās that the polytheists are inherently unclean. ${ }^{28} H o w e v e r, a l-$ Rāzì does not completely exclude this opinion by stating that it is possible for man to be dirty in terms of his nature/creation. Indeed, stating that the apparent meaning of the verse expresses that the polytheists are dirty and that the provision expressed in a verse can only be reversed if there is another nass, al-Rāzi argues that the polytheists is possible to be dirty in terms of nature. In this context, al-Rāzī states that especially al-Zamakhsharī bases his view that the polytheists are clean physically on two grounds and criticizes alZamakhshari for these reasons. The first reason of al-Zamakhshari is that he is based on the accounts that the Prophet drank water from the vessels of the polytheists, and the second reason is that it is not possible for the polytheists, who are actually dirty, to be clean when they become Muslims.

Al-Rāzī thinks that al-Zamakhsharì's objections and justifications are not acceptable. AlRāzī, who thinks that polytheists are dirty in terms of creation, states that those who hold this opinion can object to the opinion of al-Zamakhshari in several respects. The first objection is the claim that the reports that the Prophet drank water from the vessels of the polytheists cannot be taken into account, since the Qur'ān is a stronger evidence than the khabar al-wähid. According to this objection, the fact that the Qur'ān's clear verse describes the polytheists as impure, while the fact that the Prophet eating and drinking from the polytheists' cups is not an acceptable justification in terms of the strength of the evidence. The second objection is the claim that, if the report in question is valid, the Prophet thought that it was halal to drink water from the polytheists' vessels was before the release of this verse. Especially al-Rāzī, who made the explanation of the second acceptance, thinks that the Qur'ān later abrogated the thought and action of the Prophet. Al-Rāzì bases his view on the acceptance that some previously legitimate practices and that living in the same environment with the unbelievers who were previously permissible, making a treaty with them, and eating and drinking from their vessels were prohibited with the 28the verse of sūrat al-Tawba, which is one of the last revealed surahs. In this context, in order to support his view that the polytheists are described as najis by revelation, al-Rāzi describes the acceptance he quoted from al-Zamakhshari that the polytheist would not be clean if he were a Muslim as an analogy made against revelation (nass), stating that this view is unacceptable. Moreover, he regards the Mu'tazilī scholars' view that an unbeliever, when he becomes a Muslim, must perform ritual ablution (ghusl) in order to remove the impurity

27 al-Ṭabarī, Jāmi' al-bayān 'an ta’vīl āy al-Qur'ān, 11/ 398; Abū 'l-Fidā’Ismā'īl b. 'Umar Ibn Kathīr, Tafsir al-Qur'ān al'Aẓim, Critical ed. Mușțafā Sayyid Muhammad et al.(Maktaba al-Cairo: Evlad al-Sheyh li Turath, 2000/1421), 7/174; al-Tha'labī, al-Kashf wa al-Bayān, 5/27; al-Bayḍ̄̄īi, Anwār at-Tanzī, 3/77; al-Ṭabarsī, Majma'al-Bayān, 5/31; at-Tūsī, at-Tibyān fiTafsìr al-Qur'ān, 5/201.

28 al-Zamakhsharī, al-Kashshāf, 3/30-31; Fakhr al-Dīn al-Rāzī, Mafātīḥ al-Ghayb, 16/ 25 
caused by infidelity as a self-contradiction and interpret it as a view that proves the idea that the polytheist should be considered existentially filthy. ${ }^{29}$

What al-Rāzì misses in this context is that in order to express the wrongness of an action in the same context, he considers being existentially dirty and describing the behavior of the person who performs that action as dirty. Indeed, al-Zamakhshari states that what is described as bad/dirty or unacceptable is the act of shirk..$^{30}$ The fact that a disbeliever performs a ritual ablution when he becomes a Muslim is a symbolic expression of his repentance into action, not because he is inherently dirty, but symbolically accepting the wrongdoing of his previous belief and deeds.

b. The view that polytheists are physically dirty because they do not pay attention to the cleanliness of their bodies and clothes and do not perform ghusl: According to this view, polytheists are described as filthy/filthiness because they do not care about the cleanliness of their bodies and clothes, that impurity is an integral part of them just like their clothes, and they do not perfrom ghusl. ${ }^{31}$ Al-Qurtubì, who handled the verse based on legal provisions, interpreted the idiom of polytheists as a state of ritual impurity (janäbah). In this context, he discussed in detail whether a polytheist who became a Muslim should perform ghusl and stated that all sects are in agreement that a Muslim should perform ghusl. Al-Qurțubi, who states that the difference of opinion among scholars on this issue is about the provision of ghusl ablution, al-Qurțubi gives Abū Thawr Ahmad as an example to the view that defends the necessity of ghusl and al-Shāfici is an example to the view that accepts ghusl as mustahab. Those who defend the necessity of ghusl base their opinions on a narration reported from the Prophet. According to this, one day the Prophet visited Thumāma and he became a Muslim. The Prophet asked him to perform ghusl, and Thumāma performs ghusl and a two-rakat prayer. Then, the Prophet says, "Your friend's Islam has become really beautiful." ${ }^{32}$ Another example given in the context of the relationship between najāsat and ghusl ablution is more remarkable in terms of clarifying the issue. This example is about whether it is necessary for people who have not reached puberty to perform ghusl when they become Muslim. For example, al-Qurțubi narrates the interpretation he presented and defended as the view of the Ahl al-Sunnah as follows: If a person became a Muslim before puberty, his performing ghusl is mustahab for him. If he converted to Islam after puberty, this person should perform ghusl with the intention of getting rid of ritual impurity. ${ }^{33}$ When this report of al-Qurțubi is interpreted in reverse, it is understood that the polytheist/unbeliever is described as a person who does not perform ghusl. Therefore, the conclusion here is that the source of impurity is not shirk/infidelity,

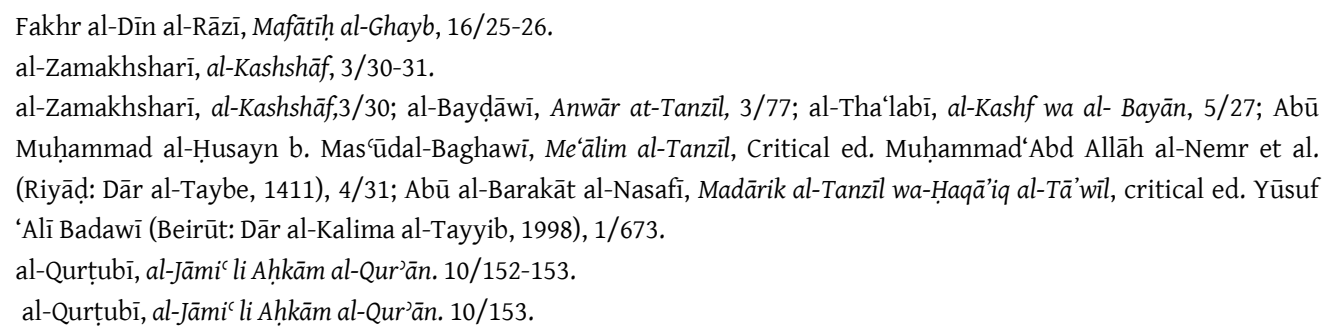


but not performing ghusl. Indeed, the states of ritual impurity, menstruation and postpartum that require performing ghusl and prevent some prayers from being performed are described as legal impurity. ${ }^{34}$ The way to be cleansed from impurity is possible by performing ghusl. It should also be noted that this view is common among the ulama. ${ }^{35}$

In the tafsirs examined, it is seen that Abū Bakr Ibn al-'Arabī examines in detail the issue that the polytheists are legally unclean. $\mathrm{He}$ is of the opinion that the polytheists are qualified as impure, not inherently or sentimentally, but in legal provisions. According to him, just as Allāh ordered man not to pray when he is in a state of spiritual impurity/hadath, ${ }^{36}$ he declared that the polytheists are impure and ordered Muslims to stay away from them. In this respect, impurity is not inherently but imperatively ${ }^{37}$ In this context, Abū Bakr Ibn al-'Arabī criticizes the Hanafī jurists' acceptance of this order as a sentimental command regarding the decree of cleansing from impurity. Because, according to him, it is judgmental, not sentimental that a place is dirty even after it has been cleaned of inherent impurity. The exegete Abū Bakr Ibn al-'Arabī, a Mālikī jurist, states that Hanafí jurists consider good and evil to be realized by a sentimental command or prohibition, since they regard good and evil as an inherent attribute. ${ }^{38}$ This criticism of Ibn al-'Arabī is based on the source of information about the nature of good and evil, which is one of the basic issues in ușūlal-figh. Because the Hanafī/Māturīdī jurists believe that good and evil are qualities of their own, they are of the opinion that good and evil are realized by a sentimental command or prohibition. On the other hand, the Shāfi $\bar{c}_{\overline{1}} / \mathrm{Ash}^{\prime}$ ari jurists argue that it is not possible for something to be good or bad in itself. These convictions lead the Shāfi īi/Ash'arī jurists to think that something may have been forbidden for a reason or a qualification other than the essence. In fact, the focal point of the debate and the reason for the emergence of differentiation is the nature of the relationship between the prohibition and the prohibited act. ${ }^{39}$ As a result, Abū Bakr Ibn al-'Arabī criticizes the Hanafis who do not think like him because he describes the impurity of polytheists as a decree and order that can be known depending on Allāh's explanation.

It is unlikely that the state of judicial pollution, which is defined as an obstacle to performing prayers, is the reason why the polytheists are described as impure. Because, in the case of situations requiring ghusl, Muslims should have also been described as impure.

34، 'Alī Muhammad b. 'Alī Sayyid Sherīf Jurjānī, al-Ta'rîfāt,Critical ed. Muhammad Bāsil Uyūn al-Sūd (Beirūt: Dār alKutub al-'Ilmiyya, 2. Edition, 2003/1424), "ḥdth”, 88.

35 al-Ṭabarī, Jāmi' al-bayān 'an ta’vīl āy al-Qur'ān, 11/ 397; al-Tha'labī, al-Kashf wa al- Bayān, 5/27; Abū Bakr Muhammad Ibn 'Abd AllāhIbn al-'Arabī, Ahkām al-Qur'ān, Critical ed.Muhammad'Abd al-Kādir Atâ (Beirut: Dār al-Kutub al'Ilmiyye, 2003/1424), 2/468.

36 Hadath refers to the state that prevents performing prayers and other acts of worship and is legally accepted as najasah/impurity. Itconsists of two parts:al-hadath al-asghar which refers to the state of non-ablution and al-hadath al-akbar which refers to a state of major ritual impuritysuch as ritual impurity, menstruation and postpartum that require performing ghusl. al-Tahānawī, Kashshäf ișțilāhāt al-funūn, "Hadath", 1/625-626.

37 Ibn al-'Arabī, Ahkām al-Qur'ān, 2/468.

38 Ibn al-'Arabī, Ahkām al-Qur'ān, 2/468-469.

39 Yunus Apaydın, “Nehiy”, Türkiye Diyanet Vakfi İslam Ansiklopedisi (Ankara: TDV Yayınları, 2006), 32/546. 
However, according to a narration from al-Ma'mar, when the Prophet met al-Hudhayfah, he took his hand in his hands, and al-Hudhayfah hesitatedly said that he was impure (junub). Thereupon, it is narrated that the Prophet said "a believer cannot be impure."40 This context quoted by al-Tabari ${ }^{-41}$ can be considered as another evidence showing that the polytheists are considered dirty not because they do not perform ghusl but because they are not Muslims. Another reason that supports this opinion is seen in the criticism of alRāzī in the context of verse 28 of sūrat al-Tawba against the Hanafí jurists to describe a Muslim without ablution as dirty. Al-Rāzī criticizes the ruling of Abū Ḥanifah hand his followers that the organs of Muslims who do not have ablution are also impure, based on the provision that the water used in ablution is impure. Al-Rāzī states that the description of the organs of Muslims without ablution as impure is contrary to the verse in question and cites the hadith of the Prophet "A believer is not dirty either alive or dead." ${ }^{42}$ as evidence for this view. ${ }^{43} \mathrm{Al}$-Rāzì says that this hadith accords with the Qur'ān and in this regard, based on the provisions given in different contexts, for example, if there is dirt on a person's clothes while performing prayer, if a person sweats without ablution and this sweat passes on his clothes, that dress will not be deemed dirty. He also states that a believer's organs are clean, and there is an agreement on this issue with verses, hadiths and ijma. ${ }^{44}$

Although the scholars, whose opinions are included within the framework of the mentioned issues, evaluate the issue through ghusl ablution, there are implications that the polytheists are considered impure due to their beliefs and their polytheistic deeds. However, this opinion is not clearly expressed. It is possible that psychosocial reasons caused scholars to cover this acceptance for different reasons.

c. The view that the polytheists are categorically spiritually dirty because they associate partners with Allāh: Another reason why polytheists are described as dirty is that they associate partners with Allāh. According to this understanding, polytheists are described as dirty in terms of belief due to the act of shirk. The polytheists were neither described as impure/filthy due to their inherent/creation, nor their inability to perform ghusl and even not to take care of their body and clothes.

40 Abū al-Husayn Muslim b. al-Hajjaj b. Muslim, Șaḥịh al-Muslim (Beirut: Dār al-Kutub al-‘llmiyye, 1991/1412), "Hayḍ̣”, 371; Abū 'Abd Allāh Aḥmad b Muḥammad al-Shaybanī Aḥmad b. Ḥanbal, Musnad al-Imam Ạ̣mad b. Ḥanbal (Beirut: Muassasa al-Risâla, 1999), 12/145.

41 al-Ṭabarī, Jāmi' al-Bayān 'an Ta'vil Āy al-Qur'ān, 11/ 397.

42 Abū 'Abd Allāh Muḥammad Ibn Ismācīl Bukhārī, Șahịḥ al-Bukhārī: al-Jāmi' al-Musnad al-ṣaḥihh, (Dimashq-Beirut: Dâr Ibn Kathīr, 2002), "Janāīz", 8.

$43 \quad$ Fakhr al-Dīn al-Rāzī, Mafätīị al-Ghayb,16/26.

${ }_{44} \quad$ Fakhr al-Dīn al-Rāzī states that the reason why Hanafis describe the organs of a Muslim without ablution as dirty is because Hanafis use the word taharah to mean cleaning from dirt. Fakhr al-Dīn al-Rāzī who criticizes giving this meaning to the word. He argues that as in the verse 33 of sūrat al-Ahzāb, taharah is used in the Qur'ān to refer to removing sins and mistakes, and also as in the verse 42 of sūrat of Āl-'Imrān, it is also used to mean that Allah clears Mary from the false accusations. Thus, for him it is not possible to accept that a believer is dirty without ablution. Fakhr al-Dīn al-Rāzī, Mafätīị al-Ghayb, 16/26-27. 
When the tafsirs discussed in terms of the view that polytheists are described as dirty due to the act of shirk, it is seen that two discourses come to the fore. The first of these consists of reporting the views that the polytheists are considered dirty due to the act of shirk. Because the commentator reports this idea not as his own opinion but as an opinion on the subject. The second discourse, on the other hand, is the view of the scholars who accept that the reason why the polytheists are described as impure is the act of shirk and who prove their thoughts on different grounds. Among the scholars who narrated that one of the reasons why polytheists were described as dirty could be shirk, al-Tha'labī, al-Zamakhsharī, al-Tabarsī, al-Qurțubi can be counted. ${ }^{45}$ Among the scholars who share the second view as their own convictions, al-Māturīdī, al-Jașsāṣ and al-Nasafí can be mentioned. ${ }^{46}$

The interpretation of al-Baydāâi, who made a different evaluation by considering the qualifications of polytheists as impure in the context of their actions of shirk is also noteworthy. Al-Bayḍāwī discusses this characterization in a sociological context. According to him, polytheists are unreliable. In this respect, najas/impure is a description that requires Muslims to be careful about their relationship with them and to understand their true intentions correctly. Al-Baydāain believes that the main warning of the divine discourse with the expression of najas means avoiding establishing a relationship based on trust with the polytheists. ${ }^{47}$

\section{Nature of the Masjid al-Ḥarām}

Another issue addressed by the ulama is the boundaries of the region that polytheists and/or unbelievers should not enter. In this context, the boundaries of the region referred to by the expression al-Masjid al-Harām in the 28th verse of the sūrat al-Tawba have been a matter of discussion. It is generally accepted that the term al-Masjid al-Harām refers to the whole area of the Harām, which is a masjid and a qibla. ${ }^{48}$ However, while some scholars define the area referred to by the term al-Masjid al-Ḥarām as a more limited place, some scholars intends to expand the boundaries of the area in question to include the entire Arabian peninsula or all the mosques of Muslims. In this framework, the views put forward regarding the borders of alMasjid al-Harām can be discussed under two sub-headings. The first is the borders of al-Masjid al-Ḥarām and the second is the location and status of the other mosques.

a. The Borders of al-Masjid al-Harām: Scholars have different views on the borders of alMasjid al-Harām, which encompasses the Kaba and refers to the area of worship. It is possible to discuss these opinions under two headings. The first one is the view that alMasjid al-Harām is limited to Mecca and its surroundings. In the context of verse 28 of

45 al-Tha'labī, al-Kashf wa al-Bayān, 5/ 27; al-Zamakhsharī, al-Kashshāf, 3/30; al-Ṭabarsī, Majma al-Bayān, 5/31; Qurțubī, al-Jāmic li Ahkām al-Qur'ān, 10/152.

46 al-Māturīdī, Ta’wīlāt al-Qur'ān, 6/324; Ābī Bakr'Ahmad Ibn 'Alī ar-Rāzī al-Jașṣāṣ, Aḥkām al-Qur'ān, Critical ed. Muhammad Sadık al-Kamhāvī, (Beirūt: Dār al-'Ihya al-Turath al-'Arabi, 1992/1412), 4/278; al-Nasafî, Madārik alTanzil, 1/673.

47 al-Bayḍ̄̄wī, Anwār at-Tanzīl,3/77.

48 al-Ṭabarī, Jāmic al-bayān 'an ta'wìl āy al-Qur'ān, 11/397; al-Qurțubī, al-Jāmic li Ahkām al-Qur'ān, 10/153; al-Tabarsī, Majma' al-Bayān, 5/31; al-Tha'labī, al-Kashf wa al-Bayān, 5/27. 
sūrat al-Tawba, the view in the tafsirs that what is meant especially by the Harām area is the borders of Mecca is more acceptable. Muqātil b. Suleymān is of the opinion that alMasjid al-Harām includes the city of Mecca. ${ }^{49} \mathrm{Al}$-Rāzī also bases his opinion on two grounds, stating that the term al-Masjid al-Ḥarām reforms to the Harām region. The first of these reasons is based on the explanation of the expression "if you fear poverty..." in the continuation of the 28th verse of sūrat al-Tawba. Al-Rāzì states that the reason why Muslims are worried about their livelihood will be not by preventing the polytheists from entering al-Masjid al-Ḥarām, but by preventing them from entering the bazaar markets in the Harām region. ${ }^{50}$ The other justification of al-Rāzī on this issue is based on the consensus of scholars on the fact that the Prophet was taken to Mir rāj from the house of Umm Hānī. Al-Rāzī states that the accuracy of this thought has increased with the expression al-Masjid al-Harām in sūrat al-Isrā' (16/1). ${ }^{51}$ Based on the fact that the Prophet was taken from the house of Umm Hāni to al-Masjid al-Aqsa and that this area was named as al-Masjid alHarām in the first verse of al-Isrā, al-Qurțubī is of the opinion that al-Masjid al-Ḥarām includes the Harām area. In order to support this view, he quotes from 'Ațā̄ b. Abī Rabāh that the whole Ḥarām area is qibla and masjid. ${ }^{52}$ Al-Shāfic'i also states that the region referred to by the phrase al-Masjid al-Ḥarām in the verse is Harām, ${ }^{53}$ but does not limit the area where polytheists and unbelievers cannot enter with the Ḥarām.

The second opinion about the borders of al-Masjid al-Harām is that this region includes the area defined as Hijaz. Hijaz "stretches from the east of the Red Sea, from Jordan's port city Eyle (Aqaba) in the north to Asir on the border with Yemen in the south and from the Najid deserts in the east to Iraq. It is controversial where the northern and eastern borders of the region end. ${ }^{54}$ The Hijaz region, which has wider borders than the Harām region, includes a limited part of the Arabian Peninsula. In the tafsir it is stated on the authority of Imām alMalik that al-Masjid al-Ḥarām includes the region consisting of Mecca, Madinah, Yamama, Yemen and the surrounding towns. ${ }^{55} \mathrm{Al}-\mathrm{Sh} a \bar{f} \mathrm{i} i \mathrm{i}$, on the other hand, is of the opinion that alMasjid al-Harām covers a wide area to include all regions counted except Yaman. ${ }^{56}$ As the borders of al-Masjid al-Ḥaām widened, non-Muslim subjects did not use this area as their living space, and their entry and exit to the region for political, commercial or travel purposes was discussed and different provisions were given on these issues. The first issue to be discussed is whether a non-Muslim envoy can enter the Harām area. Indeed, it is Harām for any non-Muslim to enter the Ḥarām region. When an envoy of a non-Muslim

\footnotetext{
${ }_{49} \quad$ Muqātil b. Suleymān, Tafsīr Muqātil b. Sulaymān, 2/165.

$50 \quad$ Fakhr al-Dīn al-Rāzī, Mafātīh al-Ghayb, 16/ 27.

51 Fakhr al-Dīn al-Rāzī, Mafātịh al-Ghayb, 16/27.

52 al-Qurțubī, al-Jāmic li Ahkām al-Qur'ān, 10/156: It is al-Baghawi who handles different views about the borders of alMasjid al-Haramin the most systematic way. For detailed information, see al-Baghawī, Ma'ālìm al-Tanzill, 4/32.

53 Muhammad b. 'Idrīs Shāfi ī̄, Aḥkām al-Qur'ān (Cairo: Maktaba al-Cānib, 1994/2014) 3. Edition, 2/61.

54 Mustafa Sabri Küçükaşç1, "Hicaz”, Türkiye Diyanet Vakfi İslam Ansiklopedisi (İstanbul: TDV Yayınları, 1997),17/434. For detailed information, see Khalid el-Awaisi,"Mapping the Sacred: The Haram Region of Makkah, Milel ve Nihal, 14/2 (2017), 25-42.

55 al-Qurțubī, al-Jāmic li Aḥkām al-Qur’ān, 10/154.

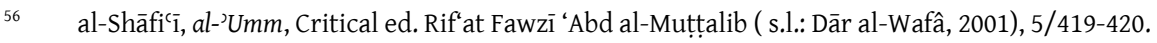


country comes to the meeting while the head of state is in the Harām region, the envoy is not allowed to enter the Harām. The head of state goes out of the Harām area called Hill to listen to the envoy's message, and the meeting is held in this way. ${ }^{57}$ If a polytheist enters the Harām secretly and gets sick there, he must be removed from the Harām as a sick person. If this person dies and is buried in the Harām unknowingly, if possible, his grave should be opened and his bones removed from the area. ${ }^{58}$ The aforementioned hypothesis of al-Rāzì is indeed noteworthy in that it shows how insistent and intolerant al-Rāzī was regarding the prevention of polytheism and polytheists from entering the Ḥarām region.

In the context of the verse 28 of sūrat al-Tawba, although al-Shāfici reports a narration from a group that he defines as scholars that al-Masjid al-Harām is the Harām region, he does not have this opinion. According to him, what is meant by this region is the Hijaz region, which includes a part of the Arabian Peninsula. He defines this region as a place where Jews and Christians, as well as polytheists, cannot use it as a living space, where non-Muslims can enter with special permission and must leave before the 3-day voyage expires and where they will not be allowed to stay even if they agree to pay the jurisdiction. ${ }^{59}$

It is seen that some hadiths are taken as a basis in determining the boundaries of the region that non-Muslims cannot enter and that legal provisions are set within this framework. For this view, such hadiths narrated from the Prophet as "I hope, I will expel Jews and Christians from the Arabian Peninsula during my life. They can only stay there as Muslims.", 60 "I will get the polytheists out of the Arabian Peninsula." ${ }^{1}$ and "Muslim and polytheists cannot coexist in the Harem after this year." ${ }^{62}$ are accepted as evidence. According to these hadiths, it is stated that only Muslims can enter the region. In addition, the claims that 'Umar and Abū Bakr acted on the basis of the hadiths of the Prophet during their caliphate are referred to as historical practices that strengthen this view. ${ }^{63}$ However, it is known that Abū Bakr did not have a practice as stated and renewed the contract with Christians. Umar excluded the Jews from Khaybar and the Christians of Najran from their living space. It is seen that Umar carried out this practice in the twentieth year of Hijra and based on reasons such as violating the socio-political, security and agreement conditions

57 al-Shāfi'ī, al-'Umm, 5/422-423; Fakhr al-Dīn al-Rāzī, Mafātīh al-Ghayb, 16/27; al-Qurțubī, al-Jāmic li Aḥkām alQur'ān,10/154; al-Baghawì,Ma'âlìm al-Tanzìl, 4/32.

58 Fakhr al-Dīn al-Rāzī, Mafätìh al-Ghayb,16/27.

59 al-Shāfi ī al, al'Umm, 5/420-421.

60 Sulaymān Ibn al-Ash'ath al-SijistānīĀbī-Dāwūd, SunanAbī-Dāwūd (Beirūt: Dâru al-Risâla al-'Ālamiyya, 2009), "Kharāj", 28 (No: 3030)

61 Muslim, Wașiyya, 5 (No: 20)

62 Rabī b. Habib b. 'Amr al-Azdī al-Basrī al-'Ummanī, Müsned: İbaziyye'nin Temel Hadis Kaynağı, çev. Orhan Ateș. (Ankara: Astana Yayınları, 2021), 150; 'Abd Allāh Ibn al-Zubayr Ḥumaydī, Musnad, Critical ed. Ḥusayn Salim Asad (Dimashq: Dār al-Sakā, 1996), 1/177 (No: 48); Abī Bakr Aḥmad Ibn al-Ḥusayn al-Bayhaqī, Ma'rifat al-Sunan wa al$\bar{A}$ thār, Critical ed. Sayyid Kawtharī Hasan (Beirut: Dâru al-Kutub al-'Ilmiyya, n.d.), 7/134; Shāficīi, Aḥkām al-Qur'ān, 2/61; al-Umm, 5/419.

63 al-Baghawī,Ma'âlìm al-Tanzīl, 4/32; al-Qurțubī, al-Jāmic li Ahkām al-Qur’ān, 10/154. 
rather than a religious reason. ${ }^{64}$ However, in the following process, the aforementioned practices of 'Umar were understood as the justification for the expulsion of non-Muslims from the Hijaz region by detaching them from their context, and they served as a source for the legal provisions produced within this framework.

Al-Shāfi ${ }^{1} \bar{c}$ claims that Allāh made it obligatory for non-Muslims/polytheists, except for the People of the Book, to be killed until they become Muslims, and the people of the book until they agree to pay tax. He explains the reason for this obligatory as the empowerment of Muslims. He bases this view on the 286th verse of sūrat al-Baqara. He states that if they are incapable of fulfilling this fard, what they can afford is imposed on them as fard. ${ }^{65} \mathrm{This}$ point of view reveals that the basic element that makes a state a state focuses on power and the principle of citizenship is ignored. This understanding, which contradicts the practices of the Prophet and determines the religious culture in the relationship to be established with the other, perceives war as an essential and peace as an incidental situation, and creates a perception of religion in this framework. With this understanding, the innate rights of man and that need to be protected have been sacrificed in the name of religion.

b. The Status of Other Masjids Compared to the Masjid-i Harām: The views of the scholars regarding the borders of al-Masjid al-Harām also determine their views on the entrance of non-Muslims to other mosques. According to the point of view that restricts the borders of al-Masjid al-Harām to the Ḥarām region, all non-Muslim people can enter the other mosques. On the other hand, it is seen that Imām al-Mālik, one of the scholars who are of the opinion that the region meant by the term al-Masjid al-Ḥarām covers a wider area, evaluates all the mosques within the framework of this verse and that non-Muslims cannot enter any mosque on earth.

Those who are of the opinion that non-Muslims can enter all mosques except al-Masjid alHarām bring as evidence that the Prophet bound Thumāma to the mosque even though he was a polytheist. They claim that if polytheists or unbelievers were not allowed to enter other mosques, the Prophet would not bind Thumāma to al-Masjid al-Nabawī ${ }^{66}$ The scholars, who believe that polytheists cannot enter any of the mosques on this issue, state that this incident, which is shown as an evidence for allowing the polytheists to enter other mosques, can be objected from different angles. The first of these objections is that the event in question took place before the verse was revealed. Since the verse was sent down later, this event has no evidentiary value. The second objection is that the Prophet bound it to the mosque because he knew that Thumāma was a Muslim before. The third objection is that the prophet did this so that when the Muslims gathered for prayer, he could see their good behavior in the mosque and their prayer, and that way he would warm up to Islam and become a Muslim. ${ }^{67}$ The first and second objections, which are shaped

64 Mustafa Fayda, Hz. Ömer Zamanında Gayr-ı Müslimler (İstanbul: Marmara Üniversitesi İlahiyat Fakültesi Yayınları, 1989)183-195.

65 al-Shāfi' 'ī, Ahkām al-Qur'ān, 2/64-65.

66 Ibn al-'Arabī, Ahkām al-Qur'ān, 2/470; al-Qurțubī, al-Jāmi' li Ahkē̄m al-Qur'ān, 10/153.

67 Ibn al-'Arabī, Aḥkām al-Qur'ān, 2/470; al-Qurțubī, al-Jāmi' li Aḥkām al-Qur'ān, 10/155-156. 
according to the view that a non-Muslim person cannot enter the mosque, are in contradiction with the third objection, which includes the view that a polytheist can enter the mosque to reconcile his heart to Islam. These justifications for the situation of Thumāma can also be considered as evidence of how scholars produce coercive ideas to support their views.

In the tafsir works examined, the opinion of Imām al-Mālik is given as an example to scholars who think that it is not permissible for polytheists to enter other mosques of Muslims. In the tafsirs, it is particularly stated that Imām al-Mālik reached his opinion by comparing the situation of al-Masjid al-Harām with other mosques. ${ }^{68}$ At the same time, as another justification of Imām Mālik's opinion, al-Qurțubi accepts the statement that an unbeliever does not know how to perform ghusl quoted by Ibn Wahb and Ibn Abī Uways on the authority of al-Imām Mālik. ${ }^{69}$ This can be seen as a reasonable justification, since impurity (janabāt) is considered an obstacle to entering the mosque. Thus, since unbelievers do not perform ghusl, they are considered dirty de jure. Therefore, it is not permissible for them to enter any mosque. According to the information quoted as the opinion of Imām al-Mālik, ${ }^{70}$ it is seen that he evaluated all groups under the name of unbeliever/non-Muslim, without making any distinction between polytheists and People of the Book.

According to Imām al-Shāfi $\overline{1}$, the verse reveals a general provision for other mosques of Muslims, and a specific provision for al-Masjid al-Harām. In this respect, polytheists and the People of the Book cannot be prevented from entering other mosques. One of the issues discussed in this context is whether non-Muslim people living in Islamic countries, defined as dhimmis, can enter the mosques. While al-Shāfici argues that dhimmis can only enter mosques only in case of need, Abū Hanīfah asserts that polytheists and dhimmis can enter Masjid al-Ḥarām and other mosques unconditionally. According to Abū Ḥanifah, the said prohibition is not about entering mosques, but about prohibiting umrah and performing hajj according to the customs of ignorance (jahiliyya).$^{71}$ However, as in the example of alQurțubī, al-Rāzī also states that this view of Abū Haniffah his not compatible with the verse and describes it as an exceptional (shädhdh) view..$^{72}$

Stating that the people of Madinah are of the opinion that the phrase al-Masjid al-Harām in the 28th verse of surah al-Tawba includes other non-Muslim people and other mosques other than the polytheists of Makkah, al-Ṭabarī and al-Qurtubī also depend 'Umar ibn 'Abd al-'Aziz's verdict on this issue. ${ }^{73}$ In the edict he sent to the governors, Umar ibn 'Abd al-

68 al-Bayḍāwī, Anwār at-Tanzīl, 3/77; al-Zamakhsharī, al-Kashshāf, 3/ 31; Fakhr al-Dīn al-Rāzī, Mafātīh al-Ghayb, 16/27.

69 al-Qurțubī, al-Jāmi li Ahkām al-Qur'ān, 10/154-156.

70 Fakhr al-Dīn al-Rāzī argues that the view that al-Imām Mālik's opinion about al-Masjid al-Haramshould be extended to all mosques is not correct, but that polytheists should be prevented from entering al-Masjid alḤaram. Fakhr al-Dīn al-Rāzī, Mafātịh al-Ghayb, 16/27.

71 al-Qurțubī, al-Jāmic li Aḥkām al-Qur'ān, 10/156; Ibn al-'Arabī, Aḥkām al-Qur'ān, 2/468-469; al-Baghawī,Ma'älìm alTanzill, 4/32.

72 al-Qurțubī, al-Jāmic li Ahkām al-Qur'ān, 10/156; Fakhr al-Dīn al-Rāzī, Mafâtîhal-Ghayb,16/27.

73 al-Ṭabarī, Jāmi' al-Bayān 'an Ta’wīl Āy al-Qur'ān, 11/398; 92; al-Qurțubī, al-Jāmi' li Aḥkām al-Qur’ān, 10/154. 
'Aziz states that Jews and Christians cannot enter the mosques. He justified this view with the 28th verse of sūrat al-Tawba. 'Umar ibn 'Abd al-'Azīz supported this view with the verse "...in houses which Allah has permitted His Name to be exalted and remembered (repeated) in them..." ${ }^{74} \mathrm{He}$ regarded the entry of unbelievers into mosques as an act against the construction of mosques and the glorification of Allāh's name in these mosques. ${ }^{75 *}$ Umar ibn 'Abd al-'Aziz's edict and practice on the subject is an important information contained in narration, judgment and Shiite tafsirs. ${ }^{76}$

During his caliphate, 'Umar ibn 'Abd al-'Azīz carried out main practices regarding nonMuslims. These practices included regulations covering many issues such as not taking part in the civil service, not taking jizya from those becoming Muslims, not wearing turbans, not wearing zunnar/leather belts, not building a new church building, not performing rites loudly etc. Although it is not included in these regulations, it is possible that he issued the decree that Jews and Christians cannot enter mosques in this context. This view of his, which is expressed especially in the tafsirs as the view of the people of Madinah, may have been influenced by the prevailing religious understanding of the people of Madinah where he received education in his childhood and later became governor there. ${ }^{77}$

As a result, it was not accepted by scholars other than Imām al-Mālik that the expression mentioned in the verse 28 of sūrat al-Tawba regarding al-Masjid al-Harām in particular to include all mosques. However, it is seen that other Imāms, apart from Abū Ḥaniffah, also bound the entrance of the polytheists to a mosque other than al-Masjid al-Harām to an obligation or permission. The main factor in their beliefs is the hadiths reported from the Prophet regarding practices such as ghusl, ablution etc. In addition, it should not be overlooked that the narration regarding the entrance of Thumāma to the mosque, which is given as an example on the subject, is interpreted in accordance with the accepted thought.

\section{The Nature of the Act of Not Approaching al-Masjid al-Harām}

Two views come to the fore regarding the nature of the act of approaching. The first of these is the perception of the act of approaching as not entering al-Masjid al-Harām, the other is the prohibition of entering for the purpose of performing hajj and umrah, as it is in ignorance. The first opinion is that of the majority of the ulama. According to this, the statement "they should not approach" to Masjid al-Ḥarām is an expression of prohibition and it is Harām to allow a person who is a polytheist to enter the Harām area. ${ }^{78}$ For this reason, polytheists cannot

\footnotetext{
74 al-Nūr 34/36.

75 al-Qurțubī, al-Jāmi' li Aḥkām al-Qur'ānn, 10/154.

76 al-Ṭabarsī, Majma al-Bayān fì Tafsīr al-Qur'ān, 5/30; Ibn Kathīr, Tafsir al-Qur'ān al-'Ažim, 7/173; al-Tha'labī, al-Kashf wa al- Bayān, 5/27; al-Qurțubī, al-Jāmi` li Aḥkām al-Qur’ān,10/154;al-Ṭabarī, Jāmi` al-Bayān 'an Ta’wìl Āy al-Qur'ān, $14 / 192$.

77 Jamāl al-Dīn'Abd al-RaḥmānAbū al-FarajIbn al-Jawzī, Sïrat 'Umar ibn 'Abd al-'Azīz, Critical ed. Na'īm Zarzūr (Beirūt: Dar al-Kutub al-'Ilmiyya, 1984/1404), 77-88.

78 al-Qurțubī, al-Jāmi` li Aḥkām al-Qur’ān, 10/153; al-Bayḍ̄āī, Anwār at-Tanzīl, 3/77; Sheyh Abū Naṣr Muhammad b. Mes'ūd al-Ayyāshī, al-Tafsīr al-Ayyāshī, Critical ed. Qism al-Dirasa al-Islamiyya (Qum: Mu’assasa al-Bi'sa, 1421), 2/
} 
approach and enter al-Masjid al-Ḥarām. Muslims are also obliged to implement this prohibition. According to this, a polytheist cannot enter the Kaba, nor can he have a service and benefit in the Harām. Because the polytheists have neither the right nor the merit to enter the region in question. ${ }^{79}$ The view that polytheists' entering the mosque would be disrespectful to the mosque is another view that should be mentioned in this context. It is also stated in the Tafsirs that the polytheists, who were described as dirty, were prohibited to enter the mosque because of its reputation and to protect this reputation. For, impurity, which is the reason why the polytheists were expelled from al-Masjid al-Harām, is accepted as a feature of the polytheists. In addition, the prohibition of polytheists/non-Muslims from entering al-Masjid al-Harām and reputation are features of the mosque. ${ }^{80}$ In addition, al-Qurțubi states that the omission of the letter "ن" in

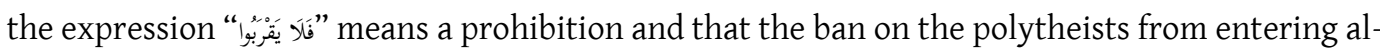
Masjid al-Ḥarām is certain. ${ }^{81}$

The view that the phrase of not approaching does not refer to prohibiting the polytheists from entering al-Masjid al-Harām, but from performing hajj and umrah, is quoted with reference to Abū Hanifah. According to this, Abū Hanifah his of the opinion that the statement "let them not approach" does not refer to the entrance of the polytheists to al-Masjid al-Harām, but refers to the prevention of their hajj and umrah, as they did in the time of ignorance in al-Masjid alHarām. ${ }^{82}$ Abu Hanifah argues that approaching al-Masjid al-Harām is an action to be done for the purpose of worship. In this respect, polytheists should not be allowed to perform any kind of worship that includes the rituals of the jahiliyya pilgrimage. In the tafsirs, it is stated that Abu Hanifah supported this view by quoting "Ali's words "Be careful, no polytheists will be able to perform pilgrimages from now on." after he read the "barâ' $a$ " 83 to the polytheists in the ninth year of the hijrah, when Abū Bakr was appointed as the amir of pilgrimage. ${ }^{84}$ However, it is seen that this view did not find enough supporters in course of time.

Although Baydāwī, states that the phrase "not to approach" can be understood as preventing non-Muslims from entering al-Masjid al-Ḥarām, it can also be understood as not allowing them to perform hajj and umrah, but he does not give any explanation as to what opinion he adopts. ${ }^{85}$

\section{The Approaches of Așhāb al-Ra'y to the Verse 28 of Sūrat al-Tawba with Reference to the Mufassirs of Hanafi-Māturīdī Tradition}

215-217; Muhammad b. Ḥasan al-Qummī, Tafsìr al-Qummī, Critical ed.Mu’assasa al-Imām al-Mahdī, (Qum: Muassa al-Imām al-Mahdī, 1435), 2/411, 406-407.

79 al-Bayḍ̄āī, Anwār at-Tanzīl, 3/77.

80 Ibn al-'Arabī, Ahkām al-Qur'ān, 2/469; al-Qurțubī, al-Jāmi' li Aḥkām al-Qur'ān,10/153-154.

81 al-Qurțubī, al-Jāmic li Aḥkām al-Qur'ān, 10/153.

82 al-Māturīdī, Ta’wīlāt al-Qur'ān,6/325; al-Zamakhsharī, al-Kashshāf, 3/30; al-Bayḍ̄āī, Anwār at-Tanzīl, 1/103; alQurțubī, al-Jāmi‘ li Aḥkām al-Qur'ān, 10/156; al-Baghawī,Ma 'ālìm al-Tanzīl, 4/32; al-Ṭabarsī, Majma' al-Bayān fi Tefsīr alQur'ān, 5/31; Ibn al-'Arabī, Ahkām al-Qur'ān, 2/469; al-Jașșās, Ahkām al-Qur'ān, s. 379.

83 The Barâ'a is another name given to the surah al-Tawba. The surah is also referred to by this name because of the word "barâ'a" mentioned in the first verse of the sūrat.

84 al-Zamakhsharī, al-Kashshāf, 2/261; al-Qurțubī, al-Jāmi`li Aḥkām al-Qur’ān, 10/156; al-Bayḍāwī, Anwār at-Tanzīl, 3/77; al-Baghawī,Ma ālìm al-Tanzill, 4/32; al-Ṭabarī, Jāmi' al-bayān 'an ta’wīl Āy al-Qur'ān, 11/399; al-Jașșāṣ, Aḥkām al-Qur'ān, s. 379.

85 al-Bayḍ̄āī, Anwār at-Tanzīl, 3/77. 
While al-Māturīiñ interprets the 28th verse of sūrat al-Tawba, he neither makes the linguistic analysis of the word najas, nor gives much information about the literature regarding the verse. It is seen that he deals with the subject through the verb polytheism. According to him, the reason why the polytheists are described as najs is they associating partners with Allah. AlMāturīdi explains why the polytheists were described as dirty due to the act of shirk on two reasons. The first of these reasons is based on the nature of human creation. Al-Māturīdī, who accepts the characteristics of humans as the potential states of human beings, is of the opinion that it is not possible for God to condemn human beings through the potential/structure created by Allāh. For, what determines man is not the states of his creation, but the actions that take place as a result of his will. In other words, God criticizes man not based on his given nature but for not using the field of possibilities that he chooses of his own will in a reasonable way. The reason why the polytheists are considered najas is that they do not use their potential in a reasonable way. The second reason al-Māturīdi put forward is that it is not possible for God to characterize human beings as subject to punishment or reward in an area where he is not involved. According to him, people are common in being human, that is, they have the same root and creation codes. What differentiates them from each other is the actions they take with their free will. People can only be reproached for their actions based on their wisdom and will which are capable of distinguishing between good and evil. ${ }^{86}$

According to al-Māturīdī, the reason why polytheists are described as najis is because they do not use their minds and commit the act of shirk. Explaining this view within the framework of the 90th verse of sūrat al-Maida, al-Māturīdī states that the elements such as alcohol, gambling etc. in the verse are the deeds of Satan and in this respect, they are described as "rics", that is, "impure". The description of polytheists as najis in the 28th verse of sūrat al-Tawba is also a description for the deeds that cause them to be idolaters. According to him, the phrase in question is satirical because of the evil of the act of associating partners with God and contradiction to reason and conscience. There is no question of the ontological criticism of the polytheists as they are of human nature. Because what affects a person is not his existential structure that changes and transforms him, but his will. ${ }^{87}$

Among the tafsirs examined, the view that the scholars of Hanīî-Māturīdi tradition considered to be najis due to the act of shirk is prevalent. One of the names exemplifying this situation is alJașsāạ. Like al-Māturīdī, al-Jașṣāṣ takes the usage areas of the words "najas" and "rijs" as basis while evaluating the subject. He states that the word "najas" is legally used to refer to something that is inherently dirty and sin, and that the word "rijs" has the same meaning. He deals with the issue through verse 90 of sūrat al-Mā’ida and verse 95 of sūrat al-Tawba, in which the word "rijs" is used in the Qur'ān. Accordingly, al-Jașạaș is of the opinion that the elements listed in the 90th verse of sūrat of al-Mā'ida are inherently unclean, and the definition of filthy in verse 95 of

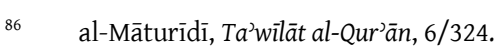

87 al-Māturīìi, Ta’wìlāt al-Qur'ān, 6/324.
} 
sūrat al-Tawba ${ }^{88}$ is due to what people do voluntarily. In this respect, according to al-Jașsāṣ, the reason why the polytheists are described as dirty is the acts of polytheism. ${ }^{89}$

Abū al-Barakāt al-Nasafī describes polytheism as a dirty way/lifestyle in terms of belief and act. He regards this act as the reason why they cannot perform ghusl and wudu and do not pay attention to body cleaning. Al-Nasafi also states that the word najas is used for hyperbole in order to express the wrongness of the act of shirk. ${ }^{90}$

In the light of the information given, the view that the polytheists are described as dirty is due to the act of shirk is argued by the scholars of the Hanifîi-Māturīdì tradition, especially by alMāturīdì. Al-Māturīdī evaluates the subject as a theologian in a moral context, starting from the fact that man is an intelligent and responsible being. In this context, al-Māturīdī asserts that the act of shirk is criticized for being a voluntary act, and emphasizes that man can only be reproached due to his willful actions. ${ }^{91}$

When the views of al-Māturīdī, al-Jașșāṣ and al-Nasafĩ about not approaching al-Masjid al-Ḥarām are examined, it is seen that they agree with Abū Hanīfah. As stated before, Abū Haniffah is of the opinion in the narration, dirayāh and aḥkām tafsirs that the act "not to approach" is a ban on performing hajj and umrah as in the time of ignorance. Describing himself as a follower of Abū Ḥaniffah, al-Māturīì also agrees with Abū Ḥanifah about the meaning of the verb "not to approach". According to al-Māturīdī, the reason why the term al-Masjid al-Ḥarām is used in the verse is that the Kaba is in the region in question. He supports this view with verses ${ }^{92}$ stating that the pilgrimage will be performed by visiting Bayt Allāh. In this respect, the ban on entering al-Masjid al-Harām is the ban on pilgrimage by polytheists. ${ }^{93}$ Because, according to him, worshiping beings other than Allāh is a kind of impurity. It is possible to purify this impurity only by getting away from worshiping beings other than Allāh. al-Māturīdī, who does not understand the phrase "let them not approach" as an absolute prohibition, did not discuss the boundaries of al-Masjid al-Harām like other mufassirs and did not specify a provision regarding who can enter this area in case of necessity. Indeed, according to him, non-Muslims who do not aim to perform pilgrimage and umrah can enter the region. Al-Māturīdī supports his view with a report from the Prophet. The Prophet assigned 'Ali to tell the convoy of pilgrimage the following four points. "Nobody but a believer can enter Paradise. The duration of a person who has an agreement with the Messenger of Allāh is until the end of the agreement. When this time is up, Allāh and His Messenger are far from the polytheists. Nobody will circumambulate the Kaba naked. After this year, no polytheists will perform pilgrimage." ${ }^{94}$ According to al-Māturīdī, the

88، They will swear to you by Allāh when you return to them so that you may turn aside from them; so do turn aside from them, surely they are unclean and their abode is hell; a recompense for what they earned."

89 al-Jașșāṣ, Ahkām al-Qur'ān, 4/278.

90 al-Nasafī, Madārik al-tanzīl, 1/673; al-Zamakhsharī, al-Kashshāf, 4/278.

91 al-Māturīdī, Ta’wīlāt al-Qur'ān, 6/324.

$92 \quad \bar{A}$ l' Imrān 3/97; al-Baqara 2/158; al-Ḥajj 22/29

93 al-Māturīdī, Ta'wīlāt al-Qur'ān, 6/325.

94 Abū'Abd al-Raḥmān 'Aḥmad ibn Shu'ayb Nasā'ī, Sunan al-Kubrā, Critical ed. Husayn 'Abd al-Mun'im Thalabī (Beirut: Mu'assasa al-Risāla 2001/1431) "Manāsik al-Ḥajj”, 161 (No. 3934). 
last of these four points reported by 'Alī shows that the ban on entering al-Masjid al-Harām is the prohibition of pilgrimage in the Kaba. ${ }^{95}$

Al-Māturīin who states that it can be objected to the view that polytheists cannot enter the mosque for pilgrimage because the expression of hajj is not mentioned in the report from 'Ali "Know that no polytheists can enter the Harām area." reveals the invalidity of this objection with another report quoted from "Alī. Accordingly, what is meant by the words of "Alī "After this year, I have called that no polytheists will perform pilgrimage." ${ }^{96}$ is that the polytheists cannot enter the Masjid al-Ḥarām in order to perform the pilgrimage. Thus, al-Māturīdī also answers any objections to his opinion. ${ }^{97}$

Al-Jașșāṣ states that the verse 28 of sūrat al-Tawba can be given meaning in two ways, and the first of these meanings is that the phrase "not to approach" is valid only for polytheists. According to this meaning, polytheists cannot enter other mosques other than al-Masjid alHarām, either they will become Muslims or they will be killed. Although al-Jaș̣āṣ does not mention this meaning given to the verse as the view of any scholar, the most important representative of this view is al-Shāfi $\overline{1}^{1}{ }^{98}$ According to al-Jașsāass, the second meaning to be given to the verse is to prevent polytheists from entering al-Masjid al-Harām for pilgrimage. He bases this view on the events that took place during the process of Abū Bakr' being sent as Hajj Amīr and states that the phrase "fear of hunger" in the following verse indicates that the prohibition is limited to the pilgrimage and the pilgrimage season. ${ }^{99}$

Al-Nasafi is of the same opinion as al-Māturīdi about the content of the verb "not to approach". Moreover, by referring to this view as "the view of our madhhab", he states that it is an original idea of the Hanīîi-Māturīdī line of thought. In this respect, he also states that it is out of question to prevent polytheists from entering the Harām, al-masjid al-Harām and other masjids. ${ }^{100}$

Another issue dealt with regarding the persons who can enter al-Masjid al-Harām is the position of polytheist slaves and concubines. Since slaves and concubines are not free, it is seen that they are allowed to enter al-Masjid al-Harām in order to fulfill the order of his master. ${ }^{101}$ In this context, it is based on the narration reported from al-Qatada. Jābir b. 'Abd Allāh's view in parallel to the said accounts that the phrase "let them not approach" generally prevents polytheists from entering the Masjid al-Harām, but there is an allocation for slaves and concubines is narrated. ${ }^{102} \mathrm{Al}$-Māturīdī shares the opinion of Jābir b. 'Abd Allāh on this issue, stating that polytheist slaves and concubines enter al-Masjid al-Harām not for the purpose of pilgrimage, but to do their masters' works, and therefore there would be no harm in their entrance. Al-Māturīdī who states that there are contradictory narrations about the position of

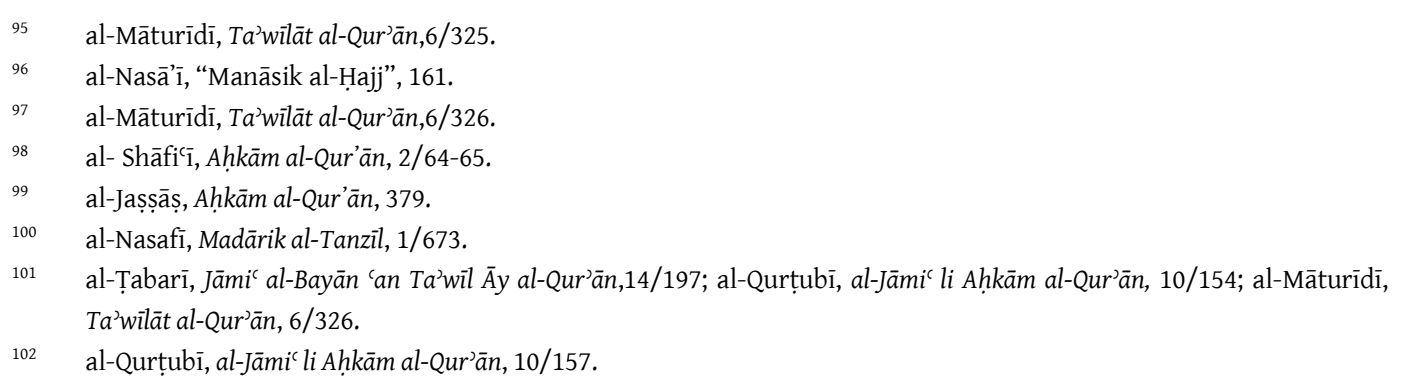


the dhimmis also argues that in another narration from Jābir b. 'Abd Allāh, the expression "or one of the dhimmis" is mentioned and this narration supports the view of Abu Hanifah There is no harm in unbeliever's entering al-Masjid al-Harām, thus there is no prohibition on entering alMasjid al-Harām in the literal meaning of the verse. ${ }^{103}$ In addition, al-Māturīdī accepts the historical and social reality that the polytheists did not leave the Harām region after this call and continued to live in this region as evidence in this context. Al-Jașsāạ is also of the opinion that slaves and concubines can enter al-Masjid al-Harām to do the work of their masters. ${ }^{104}$

Although Abū Ḥanīfah, al-Māturīdī, al-Jașșāṣ and al-Nasafī who are considered in Așhāb al-Ra'y limit the phrase of non-approach in the verse to the worship of hajj and umrah, the general opinion of the scholars is that the polytheists/non-Muslims are prohibited from entering alMasjid al-Harām for whatever purpose. The fact that the practice has been in this direction in the historical process can be seen as another indicator that the said view of the tradition of $A b \bar{u}$ Ḥanīfah and al-Māturīdī has not been accepted.

\section{Conclusion}

The 28th verse of sūrat al-Tawba is one of the verses that scholars take as the basis of the relationship to be established with non-Muslims. The fact that the polytheists are described as najs in the verse constitutes evidence of serious debates and differences of opinion regarding the nature of this description and whether these people can enter al-Masjid al-Harām. In order to determine the opinions put forward on the subject, the riwāyah, dirayāh and ạkām and Shiite tafsir written until the seventh century of the Hijra are examined. The purpose of examining the tafsirs composed with different methods is to determine how the subject is handled within the framework of different perspectives.

It is seen that the same narrations and views on the subject are included in the analyzed tafsirs. It is possible to follow the traces of the scholars' understanding of God, man and the universe based on the views of the Imāms of the madhhabs and the legal judgments they gave based on these views. In fact, the point of view regarding the impurity of the polytheists and their not approaching the Masjid al-Harām can be regarded as a landmark for reading these worldviews. In this context, when the literature formed in the context of the 28th verse of surrat al-Tawba is examined in general, it is understood that Imām al-Mālik and Imām al-Shāficī's views played an active role in the situations of the polytheists and in the fiqh literature composed about them in the historical process. In this framework, it is seen that a remarkable literature has been created on the provisions regarding all groups considered within the category of non-Muslims, not just polytheists, and regarding the limits of the political, economic and social relations to be established with these groups. The most important detail that draws attention here is the legitimization of the marginalization of the persons and groups in question especially from a socio-cultural point of view. As a parallel reflection of this point of view, the fact that Imām alMālik and Imām al-Shāfici extended the borders of al-Masjid al-Harām to cover a large part of the Arabian Peninsula, that non-Muslims were not allowed to use this area as a living space and

\footnotetext{
103 al-Māturīdī, Tawīlāt al-Qur'ān,6/326.

104 al-Jașșāṣ, Ahkām al-Qur'ān, 380.
} 
that they had to leave the area before exceeding the three-day voyage period determined for the journey are important examples of the exclusionary and intolerant perspective. Even Imām alShāfici is of the opinion that it is obligatory ( $f a r d)$ to kill the polytheists until they become Muslims and the people of the book until they pay tax. This attitude prevents Muslims, who should be the representatives of peace and tranquility, from contributing to the culture of coexistence, as well as contradicting the perspective of the Qur'ān, which is based on respect for human beings. In this context, the approaches of Abū Hanifah, one of the important representatives of Așhāb al-Ra'y, and his follower al-Māturīdī gain more importance.

Abū Hanifah evaluates the issue through the act of shirk and understands the phrase of not approaching al-Masjid al-Ḥarām as not being entered the region by the people in question in order to perform pilgrimage and umrah, as in the period of ignorance. In this respect, he does not make any comments that would allow a negative practice regarding non-Muslims, and he proves this view with 'Alī's understanding at the time the verse was sent down. This view of Abū Ḥanifah was further developed by Abū Manșūr al-Māturīdī. In the ongoing process, it is seen that this view was followed by such Ḥanîfi-Māturīdī scholars as al-Jașșāṣ and Abū al-Barakāt alNasafi. However, the views of these scholars did not find much support; moreover, they were described as exceptional (shadhdh) view.

Among the examined Shiite tafsirs, the most detailed information is seen in al-Tabarsi's work. al-Tabarsī's work contains the information in the riwāyah, dirayāh and ahkām tafsirs examined in relation to the subject. Al-Tūsĩ reports the information about the meaning field of the word najis. al-Ayyāshī and al-Qummī argue that polytheists cannot enter al-Masjid al-Ḥarām to worship as they did during the time of ignorance. However, it has been identified that the subject is not handled in detail in the Shiite tafsir works and does not contain a different opinion than the other tafsir works.

The interpretations of the Ḥanîî-Māturīdī scholars regarding the 28th verse of sūrat al-Tawba are the most important indicators that they have a distinctive human imagination independent of the dominant culture. Especially, al-Māturīdi believes that all people created by Allāh have the same nature, regardless of their ethnic origin, belief and thought, and that they are respectable because of this nature. In this context, it is necessary to distinguish between the innate structure of the human being and the identity and personality formed as a result of lifelong preferences. This identity and personality formed by human beings throughout their life is open to change and development as a result of knowledge and experience. It is the duty of Muslims to provide people with a suitable environment and opportunity for this development and change. 


\section{References}

al-Ālūsī, Shihābuddīn Maḥmud. Rūḥ al-Ma'ānī fì Tafsīr al-Qur'ān al-'Aẓim wa al-Sab` al-Mațānī. 31 Vol. Beirut: Ihyya Turāth al-Arabī, n.d.

al-Ayyāshī, Sheyh Abū Nașr Muhammad b. Mas'ūd.al-Tafsīr al-Ayyāshī, Critical ed. Q1sm alDirasa al-Islamiyya. 3 Vol. Qum: Mu'assasa al-Bi'sa, 1421.

Apaydın, Yunus. "Nehiy". Türkiye Diyanet Vakfi İslam Ansiklopedisi. 32/544-547. Ankara: TDV Yayınları, 2006.

al-Baghawī,Abû Muhammad al-Ḥusayn b. Mas'ūd. Ma'ālim al-Tanzìl. Critical ed. Muhammad 'Abd Allāh al-Nemr et al. 8 Vol. Riyaḍ: Dār al-Tayba, 1411.

al-Bayḍ̄āī, 'Abd Allāh Ibn 'Umar Muhammad. Anwār al-Tanzīl wa Asrār al-Te’vīl. Critical ed. Muhammad 'Abd al-Raḥmān al-Marashlı. 5 Vol. Beirūt: Dār al-Ihyā wa al-Turās al-'Arabī, n.d.

al-Bayhaqī, Abī Bakr Aḥmad ibn al-Ḥusayn. Ma'rifat al-Sunan wa-al-Āthār. Critical ed. Sayyid Kawtharī Hasan. Beirut: Dāru al-Kutub al-'Ilmiyya, n.d.

al-Bukhārī, Abū 'Abd Allāh Muḥammad Ibn Ismācīl. Șahịh al-Bukhārī: al-Jāmi' al-Musnad al-Ṣahịh. Dimashq-Beirut: Dâr Ibn Kathīr, 2002.

al-Jașṣāṣ, Abī Bakr Aḥmad Ibn 'Alī ar-Rāzī. Aḥkām al-Qur’ān. Critical ed. Muhammad Sadık alKamhāwī. 5 Vol. Beirut: Dār al-'Ihya al-Turath al-‘Arabi, 1992/1412.

al-Djawharī, Abū Nașr İsmāīl b. Ḥammād. Mu'jam al-Șihah, Critical ed. Aḥmad 'Abd-al-Ġafūr 'Ațțār. 6 Vol. Beirut: Dār al-‘Ilm li al-Malāyīn, 1979/1399.

al-Jurjānī, 'AlīMuhammad b. 'Alī Sayyid Sharīf.al-Ta'rîfāt, Critical ed. Muhammad Bāsil Uyūn alSūd. Beirut: Dār al-Kutub al-'Ilmiyya, 2. Edition, 2003/1424.

Abū al-Faraj Ibn al-Jawzī, Jamāl al-Dīn`Abd al-Rahmān.Sīrat 'Umar ibn 'Abd al-'Azīz. Critical ed. Na'īm Zarzūr. Beirūt: Dar al-Kutub al-'Ilmiyya, 1984/1404.

Çucak, Muhammed. "Gayrimüslümlerin Temiz Olup-Olmamasının Değerlendirilmesi ve Fıkhî Sonuçları”. Bülent Ecevit İlahiyat Fakültesi Dergisi 4/1(2017), 55-72.

Ābī-Dāwūd, Sulaymān Ibn al-Ash'ath al-Sijistānì.Sunan Abī-Dāwūd. 7 Vol. Beirūt: Dâru al-Risâla al‘Ālamiyya, 2009.

Abū Ḥayyān al-Andulisī Muhammad ibn Yūsuf.al-Bahru'l-Muhịṭ.Critical ed. 'Adil Aḥmad 'Abd alMawjūd et al. 8 Vol. Beirūt: Dār al-Kutub al-'Ilmiyye, 1993/1413.

el-Awaisi, Khalid."Mapping the Sacred: The Haram Region of Makkah, Milel ve Nihal, 14/2 (2017), 24-47.

Fayda, Mustafa. Hz. Ömer Zamanında Gayr-ı Müslimler. İstanbul: Mamarama Üniversitesi İlahiyat Fakültesi Yayınları, 1989. 
Ahmad b. Ḥanbal, Abū 'Abd Allāh Ahmad b Muhammad al-Shaybanī.Musnad al-Imam Ạmmad b. Hanbal. 50 Vol. Beirūt: Mu’assasa al-Risâla, 1999.

al-Ḥumaydī, Abd Allāh Ibn al-Zubayr. Musnad.Critical ed. Ḥusayn Salim Asad. Dımashq: Dār alSakā, 1996.

Ibn Durayd, Abū Bakr Muhammed b. al-Ḥasan. Djamharaal-Lughah. Critical ed. Remzī Munīr alBa'labakkī. 3 Vol. Beirūt: Dār al-'Ilm li al-Malāyīn, 1987.

Ibn Abī Hāāim, Abū Muhammad 'Abd al-Rahmān. Tafsìr al- Qur'ān al-'Azīm. Criticaled. As'ad Muhammad Tayyib. 10 Vol. Riyaḍ: Maktaba al-Nizār Muștafā, 1997/1417.

Ibn Fāris, Abū Ḥusayn Aḥmad. Mújamu Maqāyīs al-Lughah. Critical ed. 'Abd al-Salām Muḥammad Harun. 6 Vol. s.l.: Dār al-Fikr, n.d.

Ibn Kathīr, Abū 'l-Fidā'Ismā̄îl b. 'Umar. Tafsir al- Qur'ān al-'Ažim. Critical ed. Mușțafā Sayyid Muhammad et al. 15 Vol. Maktaba al-Cairo: Awlād al-Sheyh li Turāth, 2000/1421.

Ibn Manzūur, Muhammed b. Mukarram. Lisān al-'Arab. Critical ed. 'Abd Allāh 'Alī al-Kabīr et al. 6 Vol. Cairo: Dār al-Ma‘̄ārif, n.d.

Ibn al-'Arabī, Abū Bakr Muhammad Ibn 'Abd Allāh. Ahkēmm al-Qur'ān. Critical ed. Muhammad 'Abd al-Kādir Atâ. 5 Vol. Beirūt: Dār al-Kutub al-‘lmiyye, 3. Edition.2003/1424.

al-Isfahānī, Abū al-Qāsim Ḥusain b. Muhammad b. Mufaḍdal al-Rāghīb. Mufradāt fì Gharīb alQư'ān. Critical ed. Muhammad Sayyid Kīlānī. Beirūt: Dār al-Ma'ārif, n.d.

Kaya, Süleyman. "Harem Bölgesine Girişin Yasaklanması (Tevbe 28. Ayetin Anlamı Bağlamında)”. AïB̈ Sosyal Bilimler Enstitüsü Dergisi 15/2 (2015), 307-332.

al-Qummī,Muḥammad b. Ḥasan. Tafsìr al-Qummī. Critical ed. Mu'assasa al-Imām al-Mahdī. Qum: Mu'assa al-Imām al-Mahdī, 1435.

al-Qurțubī, Muhammad b. Aḥmad. al-Jāmic li Aḥkām al-Qur'ān. Critical ed. 'Abd Allāh bin 'Abd alMuhsin al-Turkī. 24 Vol. Beirūt: Mu’asasa al-Risāla, 2006.

Küçükaşçı, Mustafa Sabri. "Hicaz”. Türkiye Diyanet Vakfı İslam Ansiklopedisi. 17/432-437. İstanbul: TDV Yayınları, 1997.

al-Māturīdī, Abū Manșūr. Tawīlāt al-Qur’ān. Critical ed. Ertuğrul Boynukalın- Proofreader Bekir Topaloğlu 14 Vol. İstanbul: Dār al- Mīzān Yayınları, 2006.

Muqātil b. Sulaymān, Abū al-Ḥasan. Tafsīr Muqātil b. Sulaymān. Critical ed. 'Abd Allāh Maḥmud Shahhāta. 5 Vol. Beirūt: Mu’assasa al-Tārīkh al-'Arabī, 2002.

Muslim, Abū al-Husayn Muslim b. al-Hajjaj b. Șahịh al-Müslim.5 Vol. Beirūt: Dār al-Kutub al'Ilmiyya, 1991/1412.

al-Nasafī, Abū al-Barakāt. Madārik al-Tanzīl wa Haqā’iq al-Tā’wīl. Critical ed. Yūsuf 'Alī Badawī. 2 Vol. Beirūt: Dār al-Kalima al-Ṭayyib, 1998.

al-Rāzī, Fakhr al-Dīn.Mafātīh al-Ghayb. 32 Vol. Beirūt: Dār al-Fikr, 1981/1401. 
al-‘Ummanī, Rebī b. Habib b. 'Amr al-Azdī al-Basrī. Müsned: İbaziyye'nin Temel Hadis Kaynağı. çev. Orhan Ateş. Ankara: Astana Yayınları, 2021.

al-Tha'labī, Abū Isḥāq. al-Kashf wa al-Bayān 'an Tafsīr al-Qur'ān. Critical ed. Imam Abū Muhammad b. Āshūr. 10 Vol. Beirūt: Dār al-Ihyā al-Turās al-'Arabī, 2002.

Soyalan, H. Mehmet. İnançla İlgili Temel Kavramlar. İzmir: Çağlayan Yayınları,1997.

al-Shāficī̄, Muhammad b. 'Idrīs.Ahkām al-Qur'ān. 2 Vol. Cairo: Maktaba al-Cānib, 3. Edition 1994/2014.

al-Shāfi'ī, Muhammad b. 'Idrīs.al-’’Umm. Critical ed. Rif'at Fevzī 'Abd al-Muțțalib. 11 Vol. s.l.: Dār al-Vafâ, 2001.

al-Ṭabarī, Muḥammad b. al-Jarīr. Jāmic al-Bayān 'an Ta’vīl Āy al-Qur'ān. Critical ed. 'Abd Allāh b. 'Abd al-Muhsin al-Turkī. 24 Vol. Cairo: Dār al-Ḥicr, 2001/1422.

al-Ṭabarsī, Emīn al-İslām al-Faḍl Ibn al-Ḥasan. Majma al-Bayān fì Tefsìr al-Qur’ān. 10 Vol. Beirūt: Dār al-Murtaḍā, 2006.

al-Tahānawī, Muhammad A'lā b. 'Alī b. Qāḍī MuhammadḤāmid.Kashshāf Iștiliāhāt al-Funūn wa al'Ulūm. Critical ed. 'Alī Dahrūj- ‘Abd Allāh Khālidĩ. 2 Vol. Beirūt: Maktaba al-Lubnān, 1996.

al-Tūsī, Abū Ca'far Muhammad b. Ḥasan. at-Tibyān fiTafsīr al-Qurāann. Critical ed. Aḥmad Ḥamid Kasīr al-Amilī. 10 Vol. s.l.: Dar al- Ihya al-Turath al-Arabī, n.d.

al-Zamakhsharī, Muhammad Ibn 'Umar.al-Kashshāf 'an Ḥaqāiq Ghavāmiḍ al-Tanzil wa 'Uyūn alAqāwil fì Wujūh al-Ta’wīl. Critical ed. Sheyh 'Adil 'Aḥmad 'Abd al-Mavjūd. 6 Vol. Riyāḍ: Maktaba alAbyekān, 1998/1418. 